\title{
Chemoproteomics of an Indole-Based Quinone Epoxide Identifies Druggable Vulnerabilities in Vancomycin-Resistant Staphylococcus aureus
}

Amogh Kulkarni, ${ }^{\dagger}$ Isha Soni, ${ }^{\ddagger}$ Dhanashree S. Kelkar, ${ }^{\S}$ Allimuthu T. Dharmaraja, ${ }^{\dagger} \|$ Rathinam K. Sankar, ${ }^{\dagger, \perp}$ Gaurav Beniwal, ${ }^{\dagger}$ Abinaya Rajendran, ${ }^{\S}$ Sharvari Tamhankar, ${ }^{\S}$

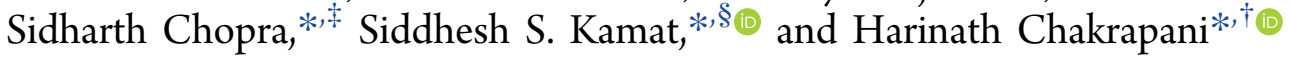

${ }^{\dagger}$ Department of Chemistry and ${ }^{\S}$ Department of Biology, Indian Institute of Science Education and Research Pune, Dr. Homi Bhabha Road, Pashan, Pune 411008, Maharashtra, India

${ }^{\ddagger}$ Division of Microbiology, CSIR-Central Drug Research Institute, Sector 10, Janakipuram Extension, Sitapur Road, Lucknow 226021, Uttar Pradesh, India

\section{Supporting Information}

ABSTRACT: The alarming global rise in fatalities from multidrugresistant Staphylococcus aureus (S. aureus) infections has underscored a need to develop new therapies to address this epidemic. Chemoproteomics is valuable in identifying targets for new drugs in different human diseases including bacterial infections. Targeting functional cysteines is particularly attractive, as they serve critical catalytic functions that enable bacterial survival. Here, we report an indole-based quinone epoxide scaffold with a unique boat-like conformation that allows steric control in modulating thiol reactivity. We extensively characterize a lead compound (4a), which potently inhibits clinically derived vancomycin-
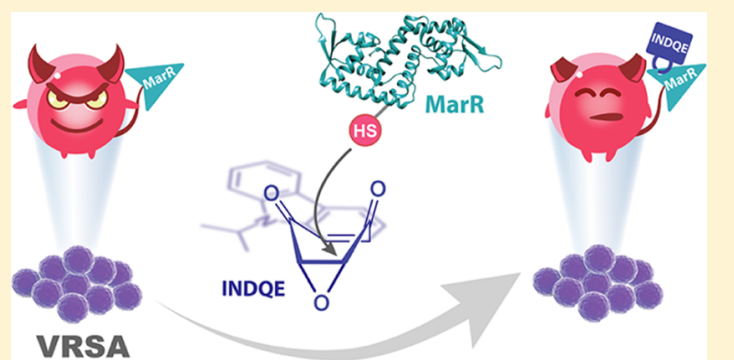
resistant $S$. aureus. Leveraging diverse chemoproteomic platforms, we identify and biochemically validate important transcriptional factors as potent targets of 4 a. Interestingly, each identified transcriptional factor has a conserved catalytic cysteine residue that confers antibiotic tolerance to these bacteria. Thus, the chemical tools and biological targets that we describe here prospect new therapeutic paradigms in combatting $S$. aureus infections.

\section{INTRODUCTION}

Clinical incidences of antimicrobial resistance (AMR) are on the rise globally and will likely render the existing pool of antimicrobial drugs ineffective. Resistance developed against these drugs makes treatment difficult and expensive. ${ }^{1}$ The bacterium Staphylococcus aureus (S. aureus) is associated with numerous nosocomial infections and can hence rapidly spread among susceptible patient populations. The emergence of resistance against vancomycin [vancomycin-resistant $S$. aureus (VRSA)] has further weakened our defence against this particular pathogen. ${ }^{2}$ Because only a few new classes of antibiotics are in the pipeline, ${ }^{3}$ identification of novel druggable biological targets is of high priority. The chemoproteomics technique, activity-based protein profiling (ABPP $)^{4}$ has emerged as a powerful tool to study and understand the native activity of enzymes in complex physiological settings, mainly utilizing the unique reactivity of serine, ${ }^{5,6}$ lysine, ${ }^{7}$ and cysteine $^{8}$ residues on the proteins. Among these, the cysteinebased ABPP has received considerable attention because thiols are excellent nucleophiles and are known to play crucial physiological roles. ${ }^{9,10}$ In order to study cysteines, thiolselective probes are being designed to pharmacologically perturb the activity of such proteins in order to understand their specific biological functions. Such probes not only help identify new druggable protein sites but can also eventually emerge as potential drug candidates. An integral part of this strategy is to identify functional cysteine residues that are vital for survival, and modification of which, may result in stress and eventual lethality to bacteria. While a number of probes are reported in literature, ${ }^{11}$ a significant portion of the proteome still remains unmined. ${ }^{8}$ Thus, there is an increasing need to develop new chemical tools to profile the thiol proteome. As a testament to the success of ABPP in identifying new bacterial proteins as targets, Sieber and co-workers have reported a suite of reactive probes to interrogate the proteome for druggable targets. $^{12-16}$ For example, using a Michael acceptor, they studied the thiol proteome of $S$. aureus and found a number of virulence factors as druggable targets. ${ }^{13}$ This and other pioneering studies ${ }^{12}$ lay a strong foundation for our approach to overcome VRSA. Here, we report the design of a new scaffold that is cell-permeable, selective in its reactivity with thiols, and has in-built structural features for modulating thiol reactivity, which helps in profiling the $S$. aureus thiol proteome.

Although several electrophilic species have been developed as thiol-selective probes, many of them suffer from diminished

Received: May 11, 2019

Published: June 26, 2019 
cell permeability and indiscriminate reactivity. ${ }^{8}$ The diversity of $\mathrm{p} K_{\mathrm{a}}$ of cysteine residues in the proteome also suggests that a single probe may likely be insufficient. The 2,3-epoxy-1,4benzoquinone functional group has been previously reported to react with protein thiols ${ }^{14,17}$ and was used as the primary thiol-reactive scaffold for this study (Figure 1). ${ }^{18,19} \mathrm{We}$ hypothesized that reactivity of this scaffold with a thiol can be modulated by systematic introduction of substituents around the epoxide (Figure 1).

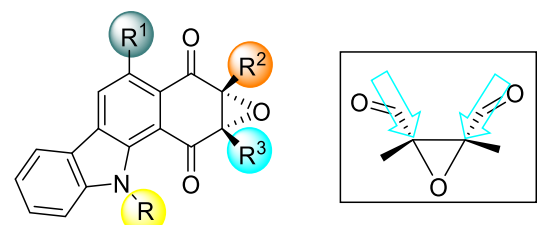

Figure 1. Proposed indole-quinone epoxide (inset: an epoxide the electrophilic reactive site in the probe, and the arrows indicate the approach of the nucleophile).

In order to achieve this, a naphthoquinone epoxide (NQE) was fused with an indole ring, and the resulting indole-based quinone epoxides (IND-QEs) were designed with two major considerations. First, because of its high rates of occurrence in natural products and drugs, indole has been considered a privileged structure. ${ }^{20}$ This typically suggests enhanced permeability and bioactivity. Second, substituting around the epoxide ring provides opportunities to modulate thiol reactivity and cell permeability. These previously unutilized structural variations will provide a systematic way to study the bacterial thiol proteome. Here, we describe the synthesis of this scaffold and generation of analogues, its structure activity studies in bacteria, their chemoproteomic profiling, and subsequent identification of the biological targets of a lead compound (4a) for this scaffold in S. aureus.

\section{RESULTS AND DISCUSSION}

Keeping the aforementioned synthetic criteria in mind, we decided to synthesize a small yet focused library of IND-QEs. In order to synthesize the desired compounds, a series of indole-based quinones (compounds $\mathbf{1 b}-\mathbf{1 5 b}, \mathbf{Q} \mathbf{1}-\mathbf{Q} 2$ ) were first synthesized using the general procedure outlined in Scheme 1.

Scheme 1. General Procedure for the Synthesis of Indolebased Quinone Epoxides: (a) $\mathrm{R}^{1} \mathrm{CH}_{2} \mathrm{PPh}_{3} \mathrm{Br}$ ( 1.15 equiv), $n$ BuLi ( 1 equiv), and THF, $-78^{\circ} \mathrm{C}$; (b) Benzoquinone $(2.5$ equiv), and Ethanol, RT<smiles>[R1]C=Cc1cn([R])c2ccccc12</smiles><smiles>[R]C1=C([R])C(=O)c2c(c([R])cc3c4ccccc4n([R])c23)C1=O</smiles>

The first series of compounds had varying substituents on the indole nitrogen (substituent $\mathrm{R}$ ). These quinones were then converted to an epoxide using $\mathrm{NaOCl}$ (Table 1). We tested the ability of these compounds to inhibit $S$. aureus ATCC 29213, and the minimum inhibitory concentration (MIC) was determined using a previously described protocol (Table 1, entries $1-5)$. $^{21,22}$
Table 1. IND-QE Analogues with Variations in R, Their MIC Values, and Reactivity with Thiol

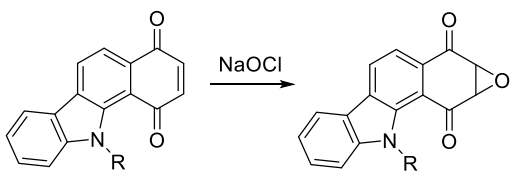

$\begin{array}{cccccc}\text { entry } & \text { compound } & \mathrm{R} & \text { yield (\%) } & \mathrm{MIC}^{a} & \text { \% remaining }^{b} \\ 1 & \text { 1a } & \mathrm{H} & 94 & 4 & 33 \\ 2 & \text { 2a } & \mathrm{Me} & 94 & 4 & 27 \\ 3 & \text { 3a } & \mathrm{Et} & 96 & 2 & 33 \\ 4 & \mathbf{4 a}^{c} & { }^{i} \mathrm{Pr} & 96 & 0.125-0.5 & 34^{d} \\ 5 & \mathbf{5 a} & \mathrm{Ph} & 82 & 2 & 57\end{array}$

${ }^{a}$ MIC in $\mu \mathrm{g} / \mathrm{mL}$ against $S$. aureus ATCC $29213 .{ }^{b}$ Determined by HPLC analysis: the compound was treated with L-cysteine (1 equiv) in $\mathrm{pH} 7.4$ phosphate buffer for $60 \mathrm{~min} .{ }^{c}$ For X-ray analysis, see Supporting Information, Figure S1. ${ }^{d}$ For the HPLC trace, see Supporting Information, Figure S2.

Based on this data, the $\mathrm{N}$-isopropyl derivative, 4a, was identified as the most potent inhibitor with a MIC of $0.125-$ $0.5 \mu \mathrm{g} / \mathrm{mL}$ (Table 1 , entry 4 ). To assess the nature of bacterial growth inhibitory activity of $\mathbf{4 a}$, a time-kill method was employed, and this compound was found to have robust bactericidal activity (see Supporting Information, Figure S3A). Next, 4a was tested against a panel of clinical drug-resistant $S$. aureus strains and was found to be a potent inhibitor of all of these, including VRSA (Table 2, entries 1-8; for the entire

Table 2. MIC $(\mu \mathrm{g} / \mathrm{mL})$ of $4 \mathrm{a}$ against Various Pathogens Including VRSA

\begin{tabular}{cllcl} 
entry & \multicolumn{1}{c}{ bacterium } & \multicolumn{1}{c}{ strain } & $\begin{array}{c}\text { MIC of } \\
\text { 4a }\end{array}$ & $\begin{array}{c}\text { MIC of } \\
\text { vancomycin }\end{array}$ \\
\hline 1 & S. aureus & SA-HIP-14300 & 0.5 & $>64$ \\
2 & S. aureus & SA-HIP-11983 & 0.5 & $32-64$ \\
3 & S. aureus & AIS100050 & 0.5 & $32-64$ \\
4 & S. aureus & SA-HIP-15178 & 0.5 & $32-64$ \\
5 & S. aureus & SA-71080 & 0.5 & $32-64$ \\
6 & S. aureus & HIP11714 & 0.5 & $>64$ \\
7 & S. aureus & HIP14300 & 0.5 & $>64$ \\
8 & S. aureus & 1002434 & 0.5 & $>64$ \\
9 & E. coli & ATCC 252922 & 64 & $<0.01^{a}$ \\
10 & K. pneumoniae & BAA 1705 & 64 & $64^{a}$ \\
11 & E. faecalis & B3119 & 64 & 0.5 \\
12 & P. aeruginosa & ATCC 27853 & 64 & 0.5 \\
13 & A. baumanii & BAA 1605 & 64 & $8^{a}$ \\
${ }^{a}$ Ciprofloxacin was used. & & \\
\end{tabular}

panel, see Supporting Information, Table S1). Time-kill analysis with VRSA strain HIP 11714 showed that 4a had a potent bactericidal activity comparable with daptomycin, a drug which is frequently used to treat VRSA infections (Figure 2A). ${ }^{23}$

Because IND-QE was designed to react with thiols (see Supporting Information, Scheme S1), we tested the propensity of these compounds to react with L-cysteine. High-performance liquid chromatography (HPLC) analysis of reaction mixtures containing the epoxide and L-cysteine revealed comparable thiol reactivity for $\mathbf{4 a}$ and its analogues during $60 \mathrm{~min}$ (Table 1, entries 1-5). A time course of consumption for $\mathbf{4 a}$ in the presence of $\mathrm{L}$-cysteine was next assessed, and this reaction followed pseudo-first-order kinetics with a rate 
A

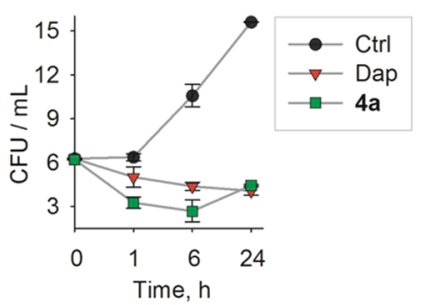

Figure 2. (A) Time-kill analysis for $4 \mathrm{a}(10 \times \mathrm{MIC}, \mathrm{MIC}=0.5 \mu \mathrm{g} / \mathrm{mL})$ and daptomycin (Dap, 10× MIC, MIC $=0.5 \mu \mathrm{g} / \mathrm{mL}$ ) against VRSA strain HIP 11714 showing potent bactericidal activity of $4 a$. For the entire plot (with vancomycin), see the Supporting Information, Figure S4, $(n=2)$; (B) Time courses of independent reactions of compounds 4a, 9a, 10a, and 11a with 10 equiv L-cysteine. Curve fitting to an exponential decay afforded pseudo-first-order rate constants, see the Supporting Information, Table S2, $(n=2)$.

constant of $7.54 \times 10^{-2} \mathrm{~min}^{-1}$ (Figure 2B). To further confirm the formation of a thiol-adduct, compound $4 \mathbf{a}$ was reacted with 4-nitro-benzyl thiol, and HPLC analysis showed the formation of a thiolated-adduct. This result was further confirmed by coelution with a synthetic standard (see Supporting Information, Figures S5 and S6, Scheme S2). Together, these data suggest that $4 \mathrm{a}$ reacts with a thiol to form a stable covalent adduct.

In order to test the ability of the IND-QE scaffold to modulate reactivity with thiols, analogues of $4 \mathbf{a}$, our lead compound, with varying $\mathrm{R}^{1}$ substituents, were synthesized (Table 3, entries 3-4). We surprisingly found that addition of

Table 3. IND-QE Analogues with Variations in $\mathbf{R}^{1}$, Their Reactivity with Thiol, and MIC Values

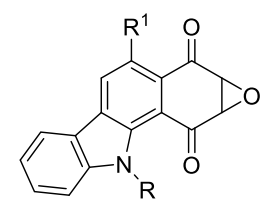

$\begin{array}{cccccc}\text { entry } & \text { compound } & \mathrm{R} & \mathrm{R}^{1} & \text { \% remaining }^{a} & \mathrm{MIC}^{b} \\ 1 & \mathbf{6 a} & \mathrm{H} & \mathrm{Me} & 86 & >16 \\ 2 & \mathbf{7 a} & \mathrm{Et} & \mathrm{Me} & 93 & 2 \\ 3 & \mathbf{8 a} & { }^{i} \mathrm{Pr} & \mathrm{Me} & 84 & 4 \\ 4 & \mathbf{9 a} & { }^{i} \mathrm{Pr} & \mathrm{Et} & 88 & 64\end{array}$

${ }^{a}$ Determined by HPLC analysis: the compound was treated with Lcysteine ( 1 equiv) in $\mathrm{pH} 7.4$ phosphate buffer for $60 \mathrm{~min} .{ }^{b} \mathrm{MIC}$ in $\mu \mathrm{g} / \mathrm{mL}$ against $S$. aureus ATCC 29213.

these substituents resulted in diminished reactivity (example, 9a, $\mathrm{R}^{1}=\mathrm{Et}$, Figure $2 \mathrm{~B}$ ). The differences in the rate constants were about 6-fold (see Supporting Information, Table S2).

While this difference is not small, it is this structural tool that provides remote control over reactivity. Given the difficulty in synthesis, preparation of compounds with the increased substituent size beyond an ethyl substituent at $\mathrm{R}^{1}$ was unsuccessful.

Intrigued by this remote substituent effect, we decided to further investigate the structural aspects that may contribute to diminished reactivity. X-ray diffraction analysis of crystalline 4a was conducted, and a boat-like conformation for the quinone epoxide was observed ${ }^{21}$ (Figure 3 ). In light of this structure, it is expected that during the thiol attack (attack at C-10, Figure 3B), one flagpole of the boat is expected to approach planarity; and this process is likely hindered by neighboring substituents. Similarly, when attack happens at the C-1 position, a similar flattening of the boat is expected. Our data suggests that the neighboring substituent does play a role. Analysis of X-ray crystallographic data showed overlapping van der Waals radii ${ }^{24}$ for the carbon attached to the nitrogen and the carbonyl adjacent to it. According to our data (see Table 1), the $\mathrm{N}$ substituent contributes to only a marginal difference in relative thiol reactivity, which is consistent with the substituent being far from the reaction center. The substituent on the C-3 $\left(\mathrm{R}^{1}\right)$ and the adjacent carbonyl also has overlapping van der Waals radii. Here, however, the substituent effect is larger, that is, 6fold. Further evidence for this trend was obtained from compounds $6 \mathbf{a}$ and $7 \mathbf{a}$, which had a methyl substituent at the $\mathrm{C}-3$ position with different substituents at the indole nitrogen (Table 3, entries 1-2). Here, we observed that the reactivity with thiol decreased uniformly in these cases (Table 3, entries $1-2)$ when compared with their unsubstituted counterparts (Table 1, entries 1 and 3). Together, these data support a preference for attack on C-1 over that on C-10.

Lastly, the analogues containing a phenyl ring on the carbons bearing the epoxide (substituents $R^{2}$ and $R^{3}$ ) were synthesized (Table 4, entries 1-2, see the Supporting Information, Scheme S3 for synthesis of substituted benzoquinone). As expected, addition of a phenyl group on the carbon bearing the epoxide had an impact on the rate of thiol-mediated disappearance of the epoxide. The rate constant for the reaction of $11 \mathrm{a}$ was determined as $0.78 \times 10^{-2} \mathrm{~min}^{-1}$ (Figure 2B). The 10-fold rate difference between $4 \mathbf{a}$ and 11a translates to roughly $1.4 \mathrm{kcal} / \mathrm{mol}$ difference in the activation barrier (see Supporting Information, Table S2). However, the analogue 10a, which had a substituent on the 10-position showed a rate difference of about 2 -fold only (Figure 2B, see Supporting Information, Table S2). Together, these data corroborate our model that the attack on C-1 is more favorable than at C-10. Recently, Diness and co-workers have reported fluorobenzene-based probes for cysteine-selective modification. ${ }^{25}$ Here, they varied the electronics on the aryl ring and
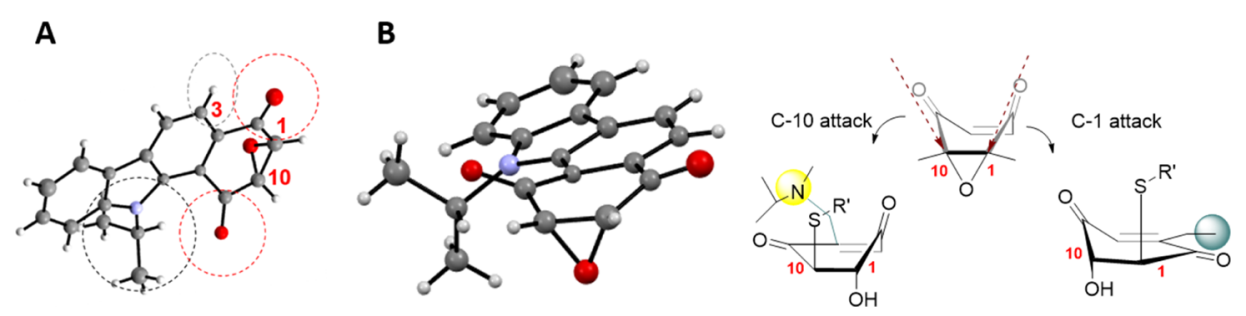

Figure 3. (A) ORTEP diagram for 4a with van der Waals radii overlap (dotted circles), for groups at $\mathrm{R}$ and $\mathrm{R}^{1}$ with carbonyl oxygens; (B) ORTEP diagram for $\mathbf{4 a}$ showing the boat-like conformation of the quinone epoxide, and schematic showing flagpole positions of quinone epoxide during the thiol attack. 
Table 4. IND-QE Analogues Synthesized in the Study and Their MIC Values

\begin{tabular}{cclll} 
& \\
entry & compd & & & \\
1 & $\mathbf{1 0 a}^{b}$ & $\mathrm{H}$ & $\mathrm{Ph}$ & $\mathrm{MIC}^{a}$ \\
2 & $\mathbf{1 1 a ^ { d }}$ & $\mathrm{Ph}$ & $\mathrm{H}$ & $>0625^{c, e}$ \\
3 & $\mathbf{1 2 a}$ & $\mathrm{H}$ & $4-\mathrm{OMePh}$ & 0.5 \\
4 & $\mathbf{1 3 a}$ & $4-\mathrm{OMePh}$ & $\mathrm{H}$ & $>64$ \\
5 & $\mathbf{1 4 a}$ & $\mathrm{H}$ & $4-\mathrm{BrPh}$ & 1 \\
6 & $\mathbf{1 5 a ^ { f }}$ & $4-\mathrm{BrPh}$ & $\mathrm{H}$ & $>64$ \\
\hline
\end{tabular}

${ }^{a} \mathrm{MIC}$ in $\mu \mathrm{g} / \mathrm{mL}$ against $S$. aureus ATCC $29213 .{ }^{b}$ For the X-ray structure of $10 \mathrm{a}$, see the Supporting Information, Figure S7. ${ }^{c}$ Timekill analysis with S. aureus ATCC 29213 showed that this compound had a bactericidal activity (see Supporting Information, Figure S3B). ${ }^{d}$ For the X-ray structure of $11 \mathrm{a}$, see the Supporting Information, Figure S8. ${ }^{e}$ For the HPLC trace, see the Supporting Information, Figure S9. ${ }^{f_{\text {For }}}$ the $\mathrm{X}$-ray structure of $15 \mathrm{a}$, see the Supporting Information, Figure S10.

found that the presence of an electron-withdrawing group increased the rate of reaction with cysteines while an electrondonating group reduced reactivity. ${ }^{26}$ This elegant design allows for tuneable reaction with thiols. For example, Pan and coworkers have earlier reported ibrutinib-based irreversible Bruton's tyrosine kinase (BTK) inhibitors and studied a series of analogues by changing the Michael acceptor group on the pyrazole. $^{27}$ This study suggests that the reactivity of the cysteine residue on BTK is critical for the inhibition and can be tuned by the structural modifications on the Michael acceptor installed. Further, leveraging advanced chemoproteomics, Cravatt and co-workers have employed alkyne-tagged irreversible probes selectively targeting EGFR (epidermal growth factor receptor) and BTK. In another study, Allimuthu and Adams have utilized 2-chloropropionamide as a steric-driven low reactivity electrophile that selectively acts as a PDI (protein disulfide isomerase) inhibitor. ${ }^{28}$ Recently, Ojida and co-workers have reported reversible modification of kinase cysteines using chlorofluoroacetamides and have explored new warheads for TCI (targeted covalent inhibition) by inhibiting EGFRs. ${ }^{29}$ With IND-QE, the possibility of tuning the thiol reactivity with varying substituent size offers a unique and complementary approach for interrogating cysteines with a large range of $\mathrm{p} K_{\mathrm{a}} \mathrm{s}$. The precise rationale for preferential attack on one carbon of the epoxide ring over the other remains to be deciphered. However, to the best of our knowledge, this is the first report where tunability of reactivity with thiol using an epoxide warhead is achieved by modulation of sterics around the electrophile. ${ }^{30-32}$

We compared the effects of these substitutions on the $S$. aureus growth inhibitory activity. In general, we observed that lowering reactivity with a thiol, reduced inhibitory activity. For example, a significant lowering of potency with the increased substituent size at $\mathrm{R}^{1}$ (Table 3, entries 3-4). We also found that the MICs of 10a and 11a against $S$. aureus were in accordance with their thiol reactivity (Table 4, entries 1-2).

Similar observations were made with their analogues (Table 4, entries 3-6), which were synthesized using similar techniques. To expand the structure-activity relationship within this scaffold and further understand the role of indole in the antibacterial activity, we synthesized NQE derivatives with and without substituent at the carbon bearing the epoxide and tested their inhibitory activity against $S$. aureus ATCC 29213 (see Supporting Information, Table S3). Not surprisingly, we found that these compounds were significantly less effective in inhibiting $S$. aureus compared to their indole counterparts. Furthermore, the quinones ${ }^{33}$ containing indoles were also relatively poor inhibitors (see Supporting Information, Table S4). Previously, Sieber and co-workers have reported aminoepoxycyclohexenones with higher MICs; one analogue with an indole tether was found to have good potency against $S$. aureus. ${ }^{14}$ Thus, the indole moiety plays a major role in enhancing the permeability and activity of this quinone epoxide scaffold.

Based on the MIC measurements, the most active compound with comparatively easier synthetic access, 4a, and an antibacterial activity comparable to that of vancomycin, was chosen as the lead compound for subsequent investigations. To assess the selectivity of this compound, we screened its antibacterial activity against Escherichia coli, $S$. aureus, Klebsiella pneumoniae, Acinetobacter baumannii, Pseudomonas aeruginosa, and Enterococcus faecalis (ESKAPE patho-
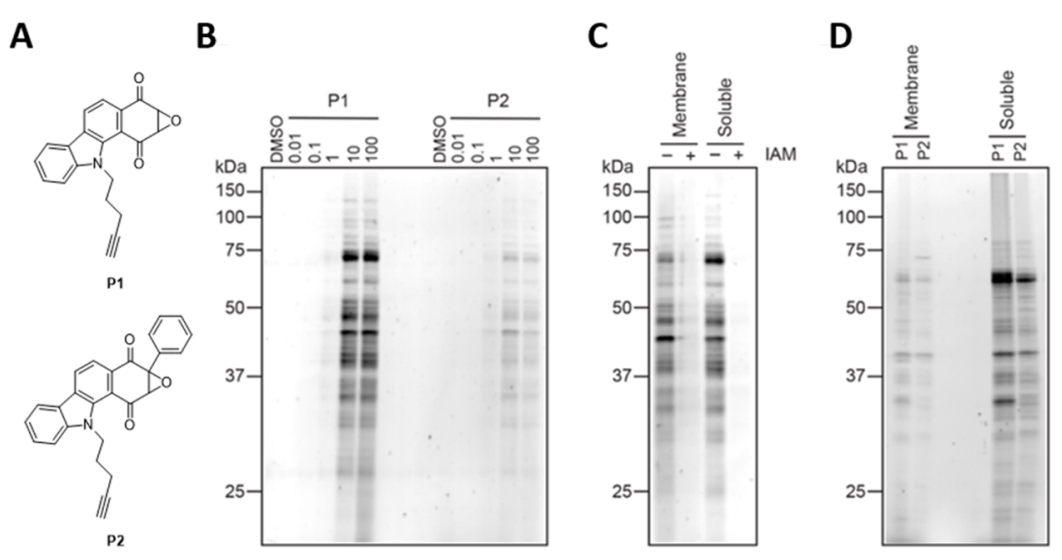

Figure 4. (A) Structures of IND-QE alkyne probes P1 and P2 synthesized in this study; (B) dose-dependent proteome profiling with P1 (0.01$100 \mu \mathrm{M})$ and P2 $(0.01-100 \mu \mathrm{M})$ in soluble proteomic fraction of $S$. aureus ATCC 29213 ; (C) proteome profiling with $10 \mu \mathrm{M}$ of P1 in lysates of $S$. aureus ATCC 29213 compared with IAM pretreated fractions; and (D) proteome profiling with $10 \mu \mathrm{M}$ of P1 and P2 in situ for S. aureus ATCC 29213. 
A

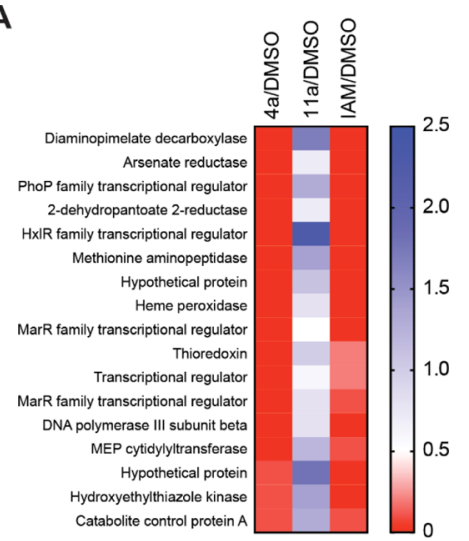

B

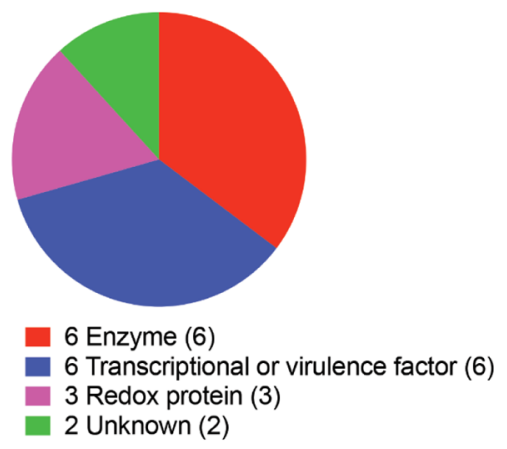

Figure 5. (A) Targets identified for $4 \mathbf{a}$ using LC-MS/MS-based proteomics experiment; proteins that exhibited ratios of $<0.1$ for $4 a$ and IAM (red color) and $\sim 1$ for 11a (blue color) were considered targets of 4a. (B) Pie-chart categorizing the identified targets of 4a.

gens) (Table 2, also see Supporting Information, Table S5). We found that $\mathbf{4 a}$ has an exquisitely selective inhibitory activity against $S$. aureus, with no significant activity against any other pathogen. Taken together, IND-QE 4a was a selective and potent inhibitor of VRSA, and thus, becomes an excellent starting point for chemoproteomic profiling to identify its biological targets.

To further understand the pharmacology, two IND-QE alkyne probes, P1 and P2, were synthesized (Figure 4A; for Xray data of P2, see Supporting Information, Figure S11) based on 4a and 11a scaffolds, respectively, that would enable bioorthogonal approaches (click chemistry) in pursuit of identifying the biological targets of $4 a$. The relative thiol reactivity of these two probes was evaluated using a competition experiment against monobromobimane, ${ }^{34}$ and both probes were found to be comparable in reactivity with their respective parent IND-QE derivatives (see Supporting Information, Figure S12, Scheme S4). We confirmed that P1 (MIC, $1 \mu \mathrm{g} / \mathrm{mL}$ ) and P2 (MIC, $>64 \mu \mathrm{g} / \mathrm{mL}$ ) had inhibitory potencies against $S$. aureus comparable to the parent compounds $4 \mathbf{a}$ and 11a respectively, and proceeded with chemoproteomics experiments using these alkyne compounds. First, S. aureus cell lysates were titrated with increasing concentrations of $\mathbf{P 1}$ and $\mathbf{P 2}$. In this experiment, compound incubation was done for $1 \mathrm{~h}$, following which $\mathrm{Cu}$-catalyzed click reaction with rhodamine-azide was carried out, and the proteomes were resolved and visualized by sodium dodecyl sulfate-polyacrylamide gel electrophoresis (SDS-PAGE) analysis using standard gel-based ABPP protocols. ${ }^{25,35}$ The gelbased ABPP experiment showed robust dose-dependent labeling of the $S$. aureus soluble protein lysate following P1 treatment but very minimal labeling with $\mathbf{P 2}$ in comparison (Figure 4B). Fractionated membrane lysates also suggested that $\mathbf{P 1}$ has robust protein reactivity, in comparison to $\mathbf{P 2}$ (see Supporting Information, Figure S13a). Qualitatively, we found from these in vitro experiments that $\mathbf{P 1}$ has more reactivity in the soluble lysates as compared to the membrane proteome.

Next, to determine if the site of labeling was indeed a protein cysteine residue, we performed a competitive gel-based ABPP experiment, where fractionated $S$. aureus cell lysates (soluble and membrane proteomes) were pretreated with excess iodoacetamide (IAM) (10 mM) and chased with P1 $(10 \mu \mathrm{M})$. We found that there was near complete ablation of P1 protein labeling when lysates were pretreated with IAM, suggesting that $\mathbf{P 1}$ indeed, and as per literature prece- dence, ${ }^{36,37}$ reacted with protein cysteine residues (Figure 4C). Further, to assess if P1 and P2 were active in situ, $S$. aureus cultures were treated with P1 and P2 for $1 \mathrm{~h}(10 \mu \mathrm{M})$, following which the cells were lysed, lysate fractionated into membrane and soluble proteomes, and the extent of P1 and P2 protein reactivity in each fraction was analysed by gel-based ABPP, following click reaction with rhodamine-azide. We found consistent result with the previously described in vitro studies, in which P1 was significantly more reactive than P2 in $S$. aureus, and the extent of reactivity was even more pronounced in the soluble proteome, suggesting that the potential biological target(s) might be soluble proteins (Figure 4D, see Supporting Information, Figure S14 for all Coomassie gels).

Given the exquisite selectivity of the lead compound $\mathbf{4 a}$ for $S$. aureus over other ESKAPE pathogens, we tried to understand the basis of selectivity and chose to chemoproteomically profile $\mathbf{P 1}$ in E. coli. We found that in vitro P1 was fairly reactive against $E$. coli lysates but had virtually no reactivity when $\mathbf{P 1}$ was used in an in situ treatment paradigm in E. coli (See Supporting Information, Figure S13b). This result suggests that this class of compounds might lack cell permeability against Gram-negative bacteria. Having obtained significantly more labeling of soluble proteins over membrane proteins from the in situ experiments, we hypothesized that the target(s) of interest would likely be present in the soluble proteome. To find the biological targets of $4 \mathrm{a}$ in $S$. aureus, we performed a competitive LC-MS/MS-based ABPP experiment. In this experiment, we incubated the $S$. aureus soluble proteome with DMSO or $4 \mathrm{a}(10 \mu \mathrm{M}, 1 \mathrm{~h})$ or $11 \mathrm{a}(10 \mu \mathrm{M}, 1$ $\mathrm{h})$ or IAM $(10 \mathrm{mM}, 1 \mathrm{~h})$, and then chased these pretreated proteomes with P1 $(10 \mu \mathrm{M}, 1 \mathrm{~h})$ and following P1 treatment performed click reaction using biotin-azide. Subsequently, the biotinylated proteins were enriched using avidin-agarose beads. Following enrichment, we performed on-bead trypsin digestion using established protocols. ${ }^{36-38}$ The tryptic peptides were subjected to LC-MS/MS analysis to identify the respective proteins enriched in each treatment group (see Supporting Information, proteomics dataset). We hypothesized that proteins, which were absent (or largely competed) in the $\mathbf{4 a}$ and IAM treatment groups (ratio relative to DMSO group $\leq 0.1$ ) but present comparable to control in the 11 a treatment group (ratio relative to DMSO group $\sim 1$ ), were likely targets of $\mathbf{4 a}$. Using these filtering criteria of the 435 proteins identified by LC-MS/MS, we found only a handful of 
proteins ( 17 proteins) that were likely targets of $\mathbf{4 a}$ (Figure 5A). Interestingly, we found from this proteomics experiment that a significant number of these protein targets of $\mathbf{4 a}$ were in fact transcriptional regulators (also known as virulence factors) (Figure 5B) that have implications in conferring antibiotic resistance to microbes ${ }^{26}$ and have to date been thought as "undruggable".

A bioinformatics survey of the amino acid sequences of the protein targets identified for $\mathbf{4 a}$ showed, as predicted, that every protein target identified from the LC-MS/MS proteomics experiment had at least one conserved cysteine residue across ESKAPE pathogens, reinforcing our hypothesis that $4 \mathbf{a}$ forms a covalent adduct with a protein cysteine residue. We were particularly interested in the two protein targets from the multiple antibiotic resistance regulon (MarR) ${ }^{39-41}$ family of transcriptional factors, namely MarR_12840 and MarR_05815, that were identified as putative targets of 4a, as previous studies have shown that inactivating mutations to either of these genes results in increased antibiotic vulnerabilities in E. coli. ${ }^{27}$

Interestingly, both these MarR proteins have only one conserved cysteine residue, Cys61 and Cys12 for MarR_12840 and MarR_05815, respectively. To validate whether these two proteins are indeed targets of $\mathbf{4 a}$, we cloned and purified these recombinant C-terminal 6X-His-tag proteins from E. coli by Ni-NTA affinity chromatography. We also made alanine point variants of Cys61 (C61A) and Cys12 (C12A) for MarR_12840 and MarR_05815, respectively. We then treated the wild type (WT) and the variant proteins with the increasing dose of P1 $(0-100 \mu \mathrm{M}, 1 \mathrm{~h})$, following which we performed click-reaction using rhodamine-azide and visualized the activity of P1 labeling by SDS-PAGE. We found for both proteins, MarR_12840 and MarR_05815, the WT variant displayed a robust dose-dependent labeling with P1, while the C61A and C12A variants of both MarR 12840 and MarR_05815, respectively, showed negligible la $\bar{b}$ eling for P1 (Figure 6). Of note, the three-dimensional structures are available for both proteins, ${ }^{28,29}$ and the Cys61 in MarR_12840 and Cys 12 in MarR 05815 are functionally important residues responsible for transcriptional activation ${ }^{42}$ and sensing cellular oxidative stress, ${ }^{43}$ respectively (Figure 6).
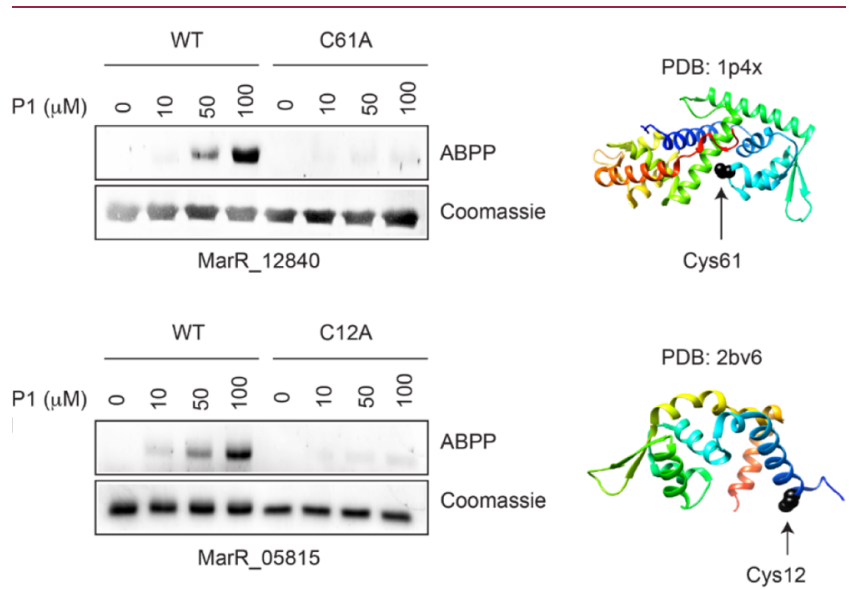

Figure 6. Dose-dependent labeling of targets MarR_12840 and MarR 05815 with varying concentrations of probe $\mathbf{P 1}$, as compared with their alanine point variants; crystal structures of identified targets with Cys residues at Cys61 and Cys12, respectively (in black spheres).
Taken together, we report a new class of cell active inhibitors against $S$. aureus, and leveraging chemoproteomics identify the biological targets for the lead compound 4a. The lead compound is highly selective in modifying cysteine residues on proteins and inhibits multidrug resistant $S$. aureus with a low MIC value. The most important identified targets are transcriptional factors, which are responsible for conferring virulence and antibiotic resistance in $S$. aureus. In a complementary approach, previously, using Michael acceptorbased ABPP, Sieber and co-workers have identified cysteine residues of SarA, SarR, and MgrA that bind to DNA as targets for inhibiting virulence that reduces bacterial pathogenicity. ${ }^{13}$ The MarR family proteins are novel druggable targets in $S$. aureus, and this is the first study, to the best of our knowledge, that reports these two putative MarR proteins as important and novel targets. This study creates novel paradigms and possibilities in combating antibiotic resistance and provides new insights into possibly novel drug targets.

As the golden era of antibiotics is nearing its end, finding new strategies to overcome antibiotic resistance is of urgent need, as it is predicted that even routine infections are likely to be untreatable by current antibiotics in the near future. This has underscored the importance of finding new druggable targets in highly prevalent pathogens such as S. aureus and VRSA. Our study reveals the importance of covalently modifying cysteine residues of transcription factors, which may have a profound impact on survival of highly drugresistant $S$. aureus. Although covalent modification of cysteine residues ${ }^{10,44}$ is frequently associated with idiosyncratic toxicities, it presents an attractive alternative to currently used drug design strategies. ${ }^{19,45}$ In this study, cytotoxicity assessment of lead compound $4 \mathrm{a}$ against mammalian cell line VERO cells showed a $\mathrm{CC}_{50}>25 \mu \mathrm{g} / \mathrm{mL}$, suggesting a higher selectivity index of $>200$ (the selectivity index of $10 a$ was also $>200$; see Supporting Information, Table S6). Additionally, we found no evidence for hemolysis at elevated concentrations suggesting that this compound did not adversely affect human erythrocytes (see Supporting Information, Figure S15).

\section{CONCLUSIONS}

Projecting ahead, we present a small molecular scaffold that lays the foundation for new approaches to address the problem of AMR. It is likely that structural optimization of this scaffold will be necessary for further development and in vivo efficacy. It has been previously demonstrated that modification of cysteines in transcription factors reduces DNA binding ability ${ }^{13}$ and hence, screening for MarR inhibitors may hold promise for identification of new antibacterial candidates. However, the inhibitory effects reported in this study might likely be due to the pharmacological disruption of more than one transcriptional factor(s), and the polypharmacological effects of $4 \mathbf{a}$ will need to be assessed by complementary genetic experiments (Figure 5B). While it may prove challenging to assess the exact extent of polypharmacological effect from a medicinal chemistry perspective, the advantages of multiple target engagements may contribute to positive attributes of $\mathbf{4 a}$. It would be extremely challenging for $S$. aureus to simultaneously generate multiple mutations in the different protein targets to develop resistance to $4 a$. With IND-QE, the structural features allowing for tunability of reactivity with cysteines coupled with excellent $S$. aureus cell permeability is a major advancement that can be leveraged to profile thiols in a variety of pathophysiologies. However, the diminished 
permeability of IND-QE in Gram-negative bacteria appears to be a significant impediment for profiling in such pathogens. This will be addressed in future studies by structural modifications that enhance permeability of the present scaffold.

\section{EXPERIMENTAL PROCEDURES (CHEMISTRY)}

All reactions were performed under a nitrogen atmosphere. All the chemicals were purchased from Aldrich, Acros, TCI, Spectrochem, Rankem, Alfa Aesar and used as received unless stated otherwise. Dichloromethane, ethanol, $N, N$-dimethylformamide, toluene, and tetrahydrofuran (THF) for reaction were used as received, and petroleum ether and ethyl acetate (EtOAc) for chromatography were distilled before use. Column chromatography was performed on Merck silica gel (60-120 mesh). ${ }^{1} \mathrm{H}$ and ${ }^{13} \mathrm{C}$ spectra were recorded on JEOL or Bruker $400 \mathrm{MHz}$ (or $100 \mathrm{MHz}$ for ${ }^{13} \mathrm{C}$ ) spectrometers using residual solvent signals as an internal standard $\left(\mathrm{CHCl}_{3}{ }^{\delta} \mathrm{H}, 7.26\right.$ ppm, $\left.{ }^{\delta} \mathrm{C} 77.2 \mathrm{ppm}\right)$ or tetramethylsilane $\left({ }^{\delta} \mathrm{H}=0.00,{ }^{\delta} \mathrm{C}=0.0\right)$. Chemical shifts $(\delta)$ are reported in ppm and coupling constants $(J)$ in Hz. The following abbreviations are used: br (broad), m (multiplet), s (singlet), d (doublet), $\mathrm{t}$ (triplet), $\mathrm{q}$ (quartet), $\mathrm{h}$ (heptet), ddd (doublet of doublet of doublet), dd (doublet of doublet), dt (doublet of triplet), dq (doublet of quartet), td (triplet of doublet), and $\mathrm{ABq}$ ( $\mathrm{AB}$ quartet). High-resolution mass spectra were obtained from HRMS-ESI-Q-time-of-flight LC/MS. FT-IR spectra were recorded using a NICOLET $6700 \mathrm{FT}$-IR spectrometer as the $\mathrm{KBr}$ disc for some compounds and using Bruker ALPHA FT-IR spectrometer for other samples, reported in $\mathrm{cm}^{-1}$. Melting point was measured using a VEEGO melting point apparatus. All melting points were measured in an open glass capillary, and the values are uncorrected. HPLC was performed on an Agilent model with a Zorbax SB C-18 reversed phase column $(250 \mathrm{~mm} \times 4.6 \mathrm{~mm}, 5 \mu \mathrm{m})$ and with a Phenomenex C-18 reversed phase column $(250 \mathrm{~mm} \times 4.6 \mathrm{~mm}, 5 \mu \mathrm{m})$. Fluorimetric and luminometric measurements were performed using a Thermo Scientific Varioskan microtiter plate reader. All compounds reported were found to be $\geq 95 \%$ pure, as determined by elemental analysis and/or HPLC analysis. HPLC traces for key compounds are included in the Supporting Information.

4.1. General Procedure for Diels-Alder Reaction. ${ }^{46}$ To a solution of the Wittig adduct in ethanol $(10 \mathrm{~mL})$, benzoquinone or arylated benzoquinone was added, and the reaction mixture was stirred at RT in an open round-bottom flask. Upon complete consumption of the starting material (TLC analysis), ethanol was evaporated from the reaction mixture under reduced pressure. Silica gel chromatography of the crude using a mixture of ethyl acetate and hexane $(1: 5, \mathrm{v} / \mathrm{v})$ as an eluent gave the pure product. This procedure was followed for the synthesis of compounds $1 \mathbf{b}-\mathbf{1 5 b}, \mathrm{Q} \mathbf{1}-\mathrm{Q} 2$.

4.2. General Procedure for Epoxidation. ${ }^{18}$ To a solution of the quinone (compounds $\mathbf{1 b}-\mathbf{1 5 b}, \mathbf{Q} \mathbf{1}-\mathbf{Q} \mathbf{2}$ ) in THF, sodium hypochlorite (9-12 wt \% in water, excess) was added, and the reaction mixture was stirred at RT in an open round-bottom flask. Upon complete consumption of the starting material (TLC analysis), the reaction mixture was diluted with water $(10 \mathrm{~mL})$ and extracted with multiple portions of ethyl acetate $(5 \times 5 \mathrm{~mL})$. The combined organic phase was washed with brine $(10 \mathrm{~mL})$, dried over anhydrous $\mathrm{Na}_{2} \mathrm{SO}_{4}$ $(5 \mathrm{~g})$, filtered and the filtrate was evaporated to dryness to get the crude product. Silica gel chromatography of the crude using a mixture of ethyl acetate and hexane $(1: 5, \mathrm{v} / \mathrm{v})$ as an eluent gave the pure product. This procedure was followed for the synthesis of compounds 1a-15a, P1-P2.

4.3. Preparation and Characterization of Compounds. 4.3.1. 1aH-Oxireno $\left[2^{\prime}, 3^{\prime}: 4,5\right]$ benzo $[1,2$-a]carbazole-2, $10(9 \mathrm{H}, 10 \mathrm{aH})$ dione (1a). Starting from $\mathbf{1 b}(70 \mathrm{mg}, 0.28 \mathrm{mmol}), \mathbf{1 a}(70 \mathrm{mg}, 94 \%)$ was isolated as an orange yellow crystalline solid: $\mathrm{mp} 226-228{ }^{\circ} \mathrm{C}$; FT-IR $\left(\nu_{\max }, \mathrm{cm}^{-1}\right): 3397,2921,1681,1587,1114 ;{ }^{1} \mathrm{H}$ NMR (400 MHz, DMSO- $\left.d_{6}\right): \delta 11.97(\mathrm{~s}, 1 \mathrm{H}), 8.58(\mathrm{dd}, J=7.9,1.6 \mathrm{~Hz}, 1 \mathrm{H})$, $8.23(\mathrm{~d}, J=7.9 \mathrm{~Hz}, 1 \mathrm{H}), 7.74(\mathrm{dd}, J=16.6,8.2 \mathrm{~Hz}, 2 \mathrm{H}), 7.50(\mathrm{t}, J=$ $7.6 \mathrm{~Hz}, 1 \mathrm{H}), 7.25(\mathrm{t}, J=7.5 \mathrm{~Hz}, 1 \mathrm{H}), 4.17(\mathrm{dd}, J=10.4,3.9 \mathrm{~Hz}, 2 \mathrm{H})$; ${ }^{13} \mathrm{C}$ NMR (100 MHz, DMSO- $\left.d_{6}\right): \delta 192.3,191.6,143.1,137.1,130.0$, $129.1,128.6$, 127.2, 121.8, 121.2, 121.0, 117.3, 114.5, 113.4, 55.8,
55.7; HRMS (ESI) for $\mathrm{C}_{16} \mathrm{H}_{9} \mathrm{NO}_{3}[\mathrm{M}+\mathrm{H}]^{+}$: calcd, 264.0655; found, 264.0660 .

4.3.2. 11H-Benzo[a]carbazole-1,4-dione (1b). Starting from 3vinyl- $1 \mathrm{H}$-indole $(510 \mathrm{mg}, 3.56 \mathrm{mmol}), \mathbf{1 b}$ was isolated as a dark redbrown solid $(560 \mathrm{mg}, 64 \%): \mathrm{mp} 251-253{ }^{\circ} \mathrm{C}$; FT-IR $\left(\nu_{\max } \mathrm{cm}^{-1}\right)$ : $1646,1566,1414,1303,1216,1114,1019 ;{ }^{1} \mathrm{H}$ NMR $(400 \mathrm{MHz}$, $\left.\mathrm{CDCl}_{3}\right): \delta 10.40(\mathrm{br}, 1 \mathrm{H}), 8.33(\mathrm{~d}, J=8.1 \mathrm{~Hz}, 1 \mathrm{H}), 8.19(\mathrm{~d}, J=7.8$ $\mathrm{Hz}, 1 \mathrm{H}), 7.92(\mathrm{~d}, J=7.9 \mathrm{~Hz}, 1 \mathrm{H}), 7.52-7.54(\mathrm{~m}, 2 \mathrm{H}), 7.28-7.32(\mathrm{~m}$, $1 \mathrm{H}), 6.93(\mathrm{~s}, 2 \mathrm{H}) ;{ }^{13} \mathrm{C} \mathrm{NMR}\left(100 \mathrm{MHz}, \mathrm{CDCl}_{3}\right): \delta 187.0,185.8$, $143.4,139.4,139.0,137.0,130.1,129.3,128.6,126.5,121.8,121.3$, 121.0, 119.9, 117.1, 113.4; HRMS (ESI) for $\mathrm{C}_{16} \mathrm{H}_{9} \mathrm{NO}_{2}[\mathrm{M}+\mathrm{H}]^{+}$: calcd, 248.0712; found, 248.0711.

4.3.3. 9-Methyl-1aH-oxireno $\left[2^{\prime}, 3^{\prime}: 4,5\right]$ benzo $[1,2$-a]carbazole$2,10(9 \mathrm{H}, 10 a \mathrm{H})$-dione (2a). Starting from $2 \mathrm{~b}(50 \mathrm{mg}, 0.19 \mathrm{mmol})$, 2a (50 mg, 94\%) was isolated as a yellow crystalline solid: mp 177$179^{\circ} \mathrm{C}$; FT-IR $\left(\nu_{\max } \mathrm{cm}^{-1}\right): 2924,1683,1471,1288,1025 ;{ }^{1} \mathrm{H}$ NMR $\left(400 \mathrm{MHz}, \mathrm{CDCl}_{3}\right): \delta 8.33(\mathrm{~d}, J=7.8 \mathrm{~Hz}, 1 \mathrm{H}), 8.10(\mathrm{~d}, J=7.8 \mathrm{~Hz}$, $1 \mathrm{H}), 7.87(\mathrm{~d}, J=8.2 \mathrm{~Hz}, 1 \mathrm{H}), 7.60(\mathrm{t}, J=7.8 \mathrm{~Hz}, 1 \mathrm{H}), 7.49(\mathrm{~d}, J=8.4$ $\mathrm{Hz}, 1 \mathrm{H}), 7.32(\mathrm{t}, J=7.5 \mathrm{~Hz}, 1 \mathrm{H}), 4.12(\mathrm{~s}, 2 \mathrm{H}), 3.80(\mathrm{~s}, 3 \mathrm{H}) ;{ }^{13} \mathrm{C}$ NMR (100 MHz, $\left.\mathrm{CDCl}_{3}\right): \delta 192.1,191.3,144.6,138.6,131.0,130.0$, $128.6,125.3,121.6,121.0,120.9,118.2,110.1,56.3,54.9,34.6$; HRMS (ESI) for $\mathrm{C}_{17} \mathrm{H}_{11} \mathrm{NO}_{3}[\mathrm{M}+\mathrm{H}]^{+}$: calcd, 278.0812; found, 278.0825 .

4.3.4. 11-Methyl-1H-benzo[a]carbazole-1,4(11H)-dione (2b). Starting from 1-methyl-3-vinyl-1 $\mathrm{H}$-indole $(1 \mathrm{~g}, 6.36 \mathrm{mmol}), 2 \mathrm{~b}$ was isolated as a dark red-brown solid $(220 \mathrm{mg}, 14 \%)$ : $\mathrm{mp} 184-186{ }^{\circ} \mathrm{C}$; FT-IR $\left(\nu_{\max } \mathrm{cm}^{-1}\right)$ : 1652, 1611, 1466, 1290, 1217, 1122, 1081, 1024; ${ }^{1} \mathrm{H}$ NMR $\left(400 \mathrm{MHz}\right.$, DMSO- $\left.d_{6}\right): \delta 8.55(\mathrm{~d}, J=8.0 \mathrm{~Hz}, 1 \mathrm{H}), 8.25(\mathrm{~d}$, $J=7.8 \mathrm{~Hz}, 1 \mathrm{H}), 7.84(\mathrm{~d}, J=8.0 \mathrm{~Hz}, 1 \mathrm{H}), 7.70(\mathrm{~d}, J=8.3 \mathrm{~Hz}, 1 \mathrm{H})$, $7.56-7.60(\mathrm{~m}, 1 \mathrm{H}), 7.30(\mathrm{t}, J=7.3 \mathrm{~Hz}, 1 \mathrm{H}), 7.10(\mathrm{~d}, J=10.2 \mathrm{~Hz}$, $1 \mathrm{H}), 7.00(\mathrm{~d}, J=10.3 \mathrm{~Hz}, 1 \mathrm{H}), 3.87(\mathrm{~s}, 3 \mathrm{H}) ;{ }^{13} \mathrm{C}$ NMR $(100 \mathrm{MHz}$, DMSO- $\left.d_{6}\right): \delta 185.7,185.6,145.3,141.0,138.8,137.0,131.0,130.7$, $128.9,125.7,121.6,121.4,118.0,111.4,35.8$; HRMS (ESI) for $\mathrm{C}_{17} \mathrm{H}_{11} \mathrm{NO}_{2}[\mathrm{M}+\mathrm{H}]^{+}$: calcd, 262.0868; found, 262.0865 .

4.3.5. 9-Ethyl-1aH-oxireno $\left[2^{\prime}, 3^{\prime}: 4,5\right]$ benzo[1,2-a]carbazole-2,10$(9 \mathrm{H}, 10 \mathrm{aH})$-dione (3a). Starting from $3 \mathbf{b}(50 \mathrm{mg}, 0.18 \mathrm{mmol})$, 3a $(51$ $\mathrm{mg}, 96 \%$ ) was isolated as a bright yellow crystalline solid: $\mathrm{mp}$ 145$147{ }^{\circ} \mathrm{C}$; FT-IR $\left(\nu_{\max } \mathrm{cm}^{-1}\right): 3042,2964,1682,1626,1432,1202$, 1131,$1026 ;{ }^{1} \mathrm{H}$ NMR $\left(400 \mathrm{MHz}, \mathrm{CDCl}_{3}\right): \delta 8.29-8.32(\mathrm{~m}, 1 \mathrm{H})$, $8.07(\mathrm{~d}, J=7.7 \mathrm{~Hz}, 1 \mathrm{H}), 7.83(\mathrm{dd}, J=9.1,2.5 \mathrm{~Hz}, 1 \mathrm{H}), 7.49-7.58$ $(\mathrm{m}, 2 \mathrm{H}), 7.30(\mathrm{t}, J=7.4 \mathrm{~Hz}, 1 \mathrm{H}), 4.36-4.51(\mathrm{~m}, 2 \mathrm{H}), 4.10-4.14(\mathrm{~m}$, $2 \mathrm{H}), 1.28(\mathrm{t}, J=7.1 \mathrm{~Hz}, 3 \mathrm{H}) ;{ }^{13} \mathrm{C}$ NMR $\left(100 \mathrm{MHz}, \mathrm{CDCl}_{3}\right): \delta 192.5$, $191.5,143.6,136.8,131.3,130.1,128.5,125.3,122.0,121.0,120.9$, $118.1,117.6,110.3,56.1,54.7,40.6$, 13.1; Elemental analysis for $\mathrm{C}_{18} \mathrm{H}_{13} \mathrm{NO}_{3}$ calcd: $\mathrm{C}, 74.22 ; \mathrm{H}, 4.50 ; \mathrm{N}, 4.81$. Found: $\mathrm{C}, 74.18 ; \mathrm{H}$, 4.33; N, 4.74; HRMS (ESI) for $\mathrm{C}_{18} \mathrm{H}_{13} \mathrm{NO}_{2}[\mathrm{M}+\mathrm{H}]^{+}$: calcd, 292.0968; found, 292.0983 .

4.3.6. 11-Ethyl-1H-benzo[a]carbazole-1,4(11H)-dione (3b). Starting from $N$-ethyl-3-vinylindole $(1 \mathrm{~g}, 5.83 \mathrm{mmol}), 3 \mathbf{b}$ was isolated as a dark red-brown solid $(285 \mathrm{mg}, 18 \%)$ : $\mathrm{mp} 138-140{ }^{\circ} \mathrm{C}$; FT-IR $\left(\nu_{\max }\right.$ $\left.\mathrm{cm}^{-1}\right): 1740,1643,1512,1443,1375,1221,1038 ;{ }^{1} \mathrm{H}$ NMR (400 $\left.\mathrm{MHz}, \mathrm{CDCl}_{3}\right): \delta 8.32(\mathrm{~d}, J=7.9 \mathrm{~Hz}, 1 \mathrm{H}), 8.07(\mathrm{~d}, J=7.7 \mathrm{~Hz}, 1 \mathrm{H})$, $8.00(\mathrm{~d}, J=8.0 \mathrm{~Hz}, 1 \mathrm{H}), 7.51-7.58(\mathrm{~m}, 2 \mathrm{H}), 7.28-7.32(\mathrm{~m}, 1 \mathrm{H})$, $6.92(\mathrm{q}, J=14.0 \mathrm{~Hz}, 2 \mathrm{H}), 4.63(\mathrm{q}, J=10.6 \mathrm{~Hz}, 2 \mathrm{H}), 1.40(\mathrm{t}, J=7.0$ $\mathrm{Hz}, 3 \mathrm{H}) ;{ }^{13} \mathrm{C}$ NMR $\left(100 \mathrm{MHz}, \mathrm{CDCl}_{3}\right): \delta 185.6,183.4,144.3,140.2$, $136.9,131.4,128.4,125.1,122.2,121.0,120.9,118.6,118.2,110.8$, 42.6, 14.4; HRMS (ESI) for $\mathrm{C}_{18} \mathrm{H}_{13} \mathrm{NO}_{2}[\mathrm{M}+\mathrm{H}]^{+}$: calcd, 276.1025; found, 276.1033 .

4.3.7. 9-Isopropyl-1aH-oxireno[2', 3':4,5]benzo[1,2-a]carbazole$2,10(9 \mathrm{H}, 10 a \mathrm{H})$-dione $(4 a)$. Starting from $4 \mathrm{~b}(70 \mathrm{mg}, 0.242 \mathrm{mmol})$, 4a (74 mg, 96\%) was isolated as a bright yellow crystalline solid: $\mathrm{mp}$ 204-206 ${ }^{\circ} \mathrm{C}$; FT-IR $\left(\nu_{\max } \mathrm{cm}^{-1}\right): 2968,1683,1622,1569,1416$, $1373,1200,1116,1026 ;{ }^{1} \mathrm{H}$ NMR $\left(400 \mathrm{MHz}, \mathrm{CDCl}_{3}\right): \delta 8.24$ (d, $J=$ $8.0 \mathrm{~Hz}, 1 \mathrm{H}), 8.06(\mathrm{~d}, J=7.8 \mathrm{~Hz}, 1 \mathrm{H}), 7.83(\mathrm{~d}, J=7.8 \mathrm{~Hz}, 1 \mathrm{H}), 7.72$ $(\mathrm{d}, J=8.5 \mathrm{~Hz}, 1 \mathrm{H}), 7.50(\mathrm{td}, J=8.2,1.0 \mathrm{~Hz}, 1 \mathrm{H}), 7.26(\mathrm{dd}, J=14.1$, $7.6 \mathrm{~Hz}, 1 \mathrm{H}), 4.64-4.74(\mathrm{~m}, 1 \mathrm{H}), 4.10(\mathrm{~s}, 2 \mathrm{H}), 1.96(\mathrm{~d}, J=6.8 \mathrm{~Hz}$, $3 \mathrm{H}), 1.39(\mathrm{~d}, J=6.9 \mathrm{~Hz}, 3 \mathrm{H}) ;{ }^{13} \mathrm{C}$ NMR $\left(100 \mathrm{MHz}, \mathrm{CDCl}_{3}\right): \delta$ $193.3,191.1,142.1,138.6,131.0,130.1,127.8,125.0,123.4,121.2$, 120.7, 118.4, 117.8, 113.9, 56.5, 54.6, 51.3, 20.7, 20.5; HRMS (ESI) for $\mathrm{C}_{19} \mathrm{H}_{15} \mathrm{NO}_{3}[\mathrm{M}+\mathrm{H}]^{+}$: calcd, 306.1125; found, 306.1126 . 
4.3.8. 11-Isopropyl-1H-benzo[a]carbazole-1,4-(11H)-dione (4b). Starting from $\mathrm{N}$-isopropyl-3-vinylindole $(765 \mathrm{mg}, 4.13 \mathrm{mmol}), 4 \mathbf{b}$ was isolated as a dark red-brown solid $(280 \mathrm{mg}, 23 \%): \mathrm{mp} 138-140{ }^{\circ} \mathrm{C}$; FT-IR $\left(\nu_{\max } \mathrm{cm}^{-1}\right): 1740,1643,1512,1443,1375,1038 ;{ }^{1} \mathrm{H}$ NMR $\left(400 \mathrm{MHz}, \mathrm{CDCl}_{3}\right): \delta 8.32(\mathrm{~d}, J=7.8 \mathrm{~Hz}, 1 \mathrm{H}), 8.05(\mathrm{~d}, J=7.7 \mathrm{~Hz}$, $1 \mathrm{H}), 7.96(\mathrm{~d}, J=7.8 \mathrm{~Hz}, 1 \mathrm{H}), 7.71(\mathrm{~d}, J=8.4 \mathrm{~Hz}, 1 \mathrm{H}), 7.44-7.48$ $(\mathrm{m}, 1 \mathrm{H}), 7.25(\mathrm{t}, J=7.4 \mathrm{~Hz}, 1 \mathrm{H}), 6.92(\mathrm{~d}, 2 \mathrm{H}), 4.85-4.96(\mathrm{~m}, 1 \mathrm{H})$, $1.71(\mathrm{~d}, J=6.9 \mathrm{~Hz}, 6 \mathrm{H}) ;{ }^{13} \mathrm{C}$ NMR $\left(100 \mathrm{MHz}, \mathrm{CDCl}_{3}\right): \delta 186.3$, $185.8,142.9,140.0,139.7,136.8,136.6,131.5,131.4,127.6,124.9$, $123.7,121.2,120.8,118.8,118.4,114.4,52.3,21.2$; HRMS (ESI) for $\mathrm{C}_{19} \mathrm{H}_{15} \mathrm{NO}_{2}[\mathrm{M}+\mathrm{H}]^{+}$: calcd, 290.1181; found, 290.1184 .

4.3.9. 9-Phenyl-1aH-oxireno $\left[2^{\prime}, 3^{\prime}: 4,5\right]$ benzo[1,2-a]carbazole$2,10(9 \mathrm{H}, 10 \mathrm{aH})$-dione $(5 \mathrm{a})$. Starting from $\mathbf{5 b}(37 \mathrm{mg}, 0.11 \mathrm{mmol})$, 5a (32 $\mathrm{mg}, 82 \%)$ was isolated as a bright yellow crystalline solid: $\mathrm{mp}$ 187-189 ${ }^{\circ} \mathrm{C}$; FT-IR $\left(\nu_{\max }\right): 2935,1687,1457,1283,1206,1110 ;{ }^{1} \mathrm{H}$ NMR $\left(400 \mathrm{MHz}, \mathrm{CDCl}_{3}\right): \delta 8.35(\mathrm{~d}, J=7.9 \mathrm{~Hz}, 1 \mathrm{H}), 8.12(\mathrm{~d}, J=7.8$ $\mathrm{Hz}, 1 \mathrm{H}), 7.90(\mathrm{~d}, J=7.9 \mathrm{~Hz}, 1 \mathrm{H}), 7.15(\mathrm{~s}, 2 \mathrm{H}), 7.42-7.49(\mathrm{~m}, 2 \mathrm{H})$, $7.31-7.36(\mathrm{~m}, 2 \mathrm{H}), 6.95(\mathrm{~s}, 1 \mathrm{H}), 3.99(\mathrm{~d}, J=4.2 \mathrm{~Hz}, 1 \mathrm{H}), 3.76(\mathrm{~d}, J$ $=4.2 \mathrm{~Hz}, 1 \mathrm{H}) ;{ }^{13} \mathrm{C}$ NMR $\left(100 \mathrm{MHz}, \mathrm{CDCl}_{3}\right): \delta 191.2,190.4,144.8$, $139.5,138.2,131.3,129.9,128.6,128.1,127.4,125.2,125.1,121.9$, 121.7, 121.0, 118.9, 117.6, 111.2, 55.9, 54.2; HRMS (ESI) for $\mathrm{C}_{22} \mathrm{H}_{13} \mathrm{NO}_{2}[\mathrm{M}+\mathrm{H}]^{+}$: calcd, 340.0968; found, 340.0974 .

4.3.10. 11-Phenyl-1H-benzo[a]carbazole-1,4(11H)-dione (5b). Starting from $N$-phenyl-3-vinylindole $(160 \mathrm{mg}, 0.73 \mathrm{mmol}), 5 \mathbf{b}$ was isolated as a dark red-brown solid (50 mg, 21\%): $\mathrm{mp} 218-220{ }^{\circ} \mathrm{C}$; FT-IR $\left(\nu_{\max }\right): 1655,1611,1463,1412,1289 ;{ }^{1} \mathrm{H}$ NMR $(400 \mathrm{MHz}$, $\left.\mathrm{CDCl}_{3}\right): \delta 8.42(\mathrm{~d}, J=7.7 \mathrm{~Hz}, 1 \mathrm{H}), 8.14(\mathrm{~d}, J=7.8 \mathrm{~Hz}, 1 \mathrm{H}), 8.10(\mathrm{~d}$, $J=7.6 \mathrm{~Hz}, 1 \mathrm{H}), 7.54(\mathrm{t}, J=7.5 \mathrm{~Hz}, 2 \mathrm{H}), 7.45(\mathrm{t}, J=7.5 \mathrm{~Hz}, 2 \mathrm{H})$, $7.26-7.36(\mathrm{~m}, 4 \mathrm{H}), 6.84(\mathrm{~d}, J=10.0 \mathrm{~Hz}, 1 \mathrm{H}), 6.67(\mathrm{~d}, J=10.0 \mathrm{~Hz}$, $1 \mathrm{H}) ;{ }^{13} \mathrm{C}$ NMR $\left(100 \mathrm{MHz}, \mathrm{CDCl}_{3}\right): \delta 185.6,184.1,145.7,141.1$, $139.6,138.3,137.1,136.7,132.0,131.2,129.3,128.6,127.7,126.5$, 125.2, 122.0, 121.8, 120.8, 119.4, 117.9, 111.9; HRMS (ESI) for $\mathrm{C}_{22} \mathrm{H}_{13} \mathrm{NO}_{2}[\mathrm{M}+\mathrm{H}]^{+}$: calcd, 324.1025; found, 324.1016.

4.3.11. 3-Methyl-1aH-oxireno $\left[2^{\prime}, 3^{\prime}: 4,5\right]$ benzo[1,2-a]carbazole$2,10(9 \mathrm{H}, 10 \mathrm{aH})$-dione $(6 \mathbf{a})$. Starting from $\mathbf{6 b}(50 \mathrm{mg}, 0.19 \mathrm{mmol})$, 6a (45 mg, 85\%) was isolated as an orange red crystalline solid: $\mathrm{mp}$ 224-226 ${ }^{\circ} \mathrm{C}$; FT-IR $\left(\nu_{\max } \mathrm{cm}^{-1}\right): 2252,1740,1643,1512,1443$, 1375,$1038 ;{ }^{1} \mathrm{H}$ NMR $\left(400 \mathrm{MHz}, \mathrm{CDCl}_{3}\right): \delta 10.16(\mathrm{~s}, 1 \mathrm{H}), 8.15(\mathrm{~s}$, $1 \mathrm{H}), 8.05(\mathrm{~d}, J=7.8 \mathrm{~Hz}, 1 \mathrm{H}), 7.47-7.52(\mathrm{~m}, 2 \mathrm{H}), 7.29(\mathrm{td}, J=5.8$ $\mathrm{Hz}, 2.2 \mathrm{~Hz}, 1 \mathrm{H}), 4.03(\mathrm{q}, J=9.5 \mathrm{~Hz}, 2 \mathrm{H}), 2.74(\mathrm{~s}, 3 \mathrm{H}) ;{ }^{13} \mathrm{C}$ NMR $\left(100 \mathrm{MHz}, \mathrm{CDCl}_{3}\right): \delta 193.4,193.2,142.1,137.4,131.5,130.2,129.2$, 128.6, 121.4, 121.0, 111.8, 55.7, 55.5, 22.0; HRMS (ESI) for $\mathrm{C}_{17} \mathrm{H}_{11} \mathrm{NO}_{3}[\mathrm{M}+\mathrm{H}]^{+}$: calcd, 278.0817; found, 278.0813.

4.3.12. 11-Ethyl-5-methyl-2,3-dihydro-1H-benzo[a]carbazole1,4(11H)-dione $(\mathbf{6 b})$. Starting from 3-(1-propenyl)-indole (1 g, 6.36 $\mathrm{mmol}), \mathbf{6 b}$ was isolated as a dark red-brown solid $(235 \mathrm{mg}, 14 \%): \mathrm{mp}$ 224-226 ${ }^{\circ} \mathrm{C}$; FT-IR $\left(\nu_{\max } \mathrm{cm}^{-1}\right): 1739,1646,1367,1224 ;{ }^{1} \mathrm{H}$ NMR $\left(400 \mathrm{MHz}, \mathrm{CDCl}_{3}\right): \delta 10.46(\mathrm{~s}, 1 \mathrm{H}), 8.05(\mathrm{~s}, 1 \mathrm{H}), 8.01(\mathrm{~d}, J=8.5$ $\mathrm{Hz}, 1 \mathrm{H}), 7.48(\mathrm{dd}, J=1.2,6.2 \mathrm{~Hz}, 2 \mathrm{H}), 7.23-7.27(\mathrm{~m}, 1 \mathrm{H}), 6.82(\mathrm{~d}, J$ $=1.9 \mathrm{~Hz}, 2 \mathrm{H}), 2.80(\mathrm{~s}, 3 \mathrm{H}) ;{ }^{13} \mathrm{C} \mathrm{NMR}\left(100 \mathrm{MHz}, \mathrm{CDCl}_{3}\right): \delta 188.1$, $187.1,142.5,140.5,137.5,136.9,132.6,129.6,128.5,126.3,121.5$, 121.2, 120.8, 115.2, 111.7, 23.5; HRMS (ESI) for $\mathrm{C}_{17} \mathrm{H}_{11} \mathrm{NO}_{2}[\mathrm{M}+$ $\mathrm{H}]^{+}$: calcd, 262.0868; found, 262.0863.

4.3.13. 9-Ethyl-3-methyl-1aH-oxireno $\left[2^{\prime}, 3^{\prime}: 4,5\right]$ benzo[1,2-a]carbazole-2,10(9H,10aH)-dione (7a). Starting from $7 \mathbf{b}(45 \mathrm{mg}$, $0.15 \mathrm{mmol}), 7 \mathrm{a}(37 \mathrm{mg}, 71 \%)$ was isolated as a yellow solid: $\mathrm{mp} 159-$ $161{ }^{\circ} \mathrm{C}$; FT-IR $\left(\nu_{\max } \mathrm{cm}^{-1}\right): 1680,1427,1258,1199,1124 ;{ }^{1} \mathrm{H}$ NMR $\left(400 \mathrm{MHz}, \mathrm{CDCl}_{3}\right): \delta 8.17(\mathrm{~s}, 1 \mathrm{H}), 8.08(\mathrm{~d}, J=7.8 \mathrm{~Hz}, 1 \mathrm{H}), 7.57(\mathrm{t}$, $J=7.6 \mathrm{~Hz}, 1 \mathrm{H}), 7.50(\mathrm{~d}, J=8.3 \mathrm{~Hz}, 1 \mathrm{H}), 7.29(\mathrm{t}, J=7.4 \mathrm{~Hz}, 1 \mathrm{H})$, $4.40(\mathrm{q}, J=14.2 \mathrm{~Hz}, 2 \mathrm{H}), 4.17(\mathrm{~d}, J=4.6 \mathrm{~Hz}, 1 \mathrm{H}), 4.13(\mathrm{~d}, J=4.5$ $\mathrm{Hz}, 1 \mathrm{H}), 2.73(\mathrm{~s}, 3 \mathrm{H}), 1.24(\mathrm{t}, J=7.1 \mathrm{~Hz}, 3 \mathrm{H}) ;{ }^{13} \mathrm{C} \mathrm{NMR}(100 \mathrm{MHz}$, $\left.\mathrm{CDCl}_{3}\right): \delta 193.7,193.4,143.9,135.5,130.5,130.3,128.4,127.8$, 121.7, 121.0, 120.6, 118.4, 110.1, 56.3, 54.6, 40.1, 21.9, 12.8; HRMS (ESI) for $\mathrm{C}_{19} \mathrm{H}_{15} \mathrm{NO}_{3}[\mathrm{M}+\mathrm{H}]^{+}$: calcd, 306.1125; found, 306.1133 .

4.3.14. 11-Ethyl-5-methyl-1H-benzo[a]carbazole-1,4(11H)-dione (7b). Starting from $N$-ethyl-3-(1-propenyl)-indole $(350 \mathrm{mg}, 1.88$ $\mathrm{mmol}), 7 \mathbf{b}$ was isolated as a dark red-brown solid $(70 \mathrm{mg}, 13 \%): \mathrm{mp}$ 132-134 ${ }^{\circ} \mathrm{C}$; FT-IR $\left(\nu_{\max } \mathrm{cm}^{-1}\right): 1740,1645,1512,1443,1375$, 1221, 1038; ${ }^{1} \mathrm{H}$ NMR $\left(400 \mathrm{MHz}, \mathrm{CDCl}_{3}\right): \delta 8.13(\mathrm{~d}, J=3.3 \mathrm{~Hz}, 1 \mathrm{H})$, $8.05(\mathrm{~d}, J=7.7 \mathrm{~Hz}, 1 \mathrm{H}), 7.50-7.57(\mathrm{~m}, 2 \mathrm{H}), 7.26-7.30(\mathrm{~m}, 1 \mathrm{H})$, $6.91(\mathrm{dd}, J=10.1,1.3 \mathrm{~Hz}, 1 \mathrm{H}), 6.84(\mathrm{dd}, J=10.1,1.3,1 \mathrm{H}), 4.51(\mathrm{dq}, J$ $=7.1,1.7 \mathrm{~Hz}, 2 \mathrm{H}), 2.83(\mathrm{~s}, 3 \mathrm{H}), 1.29(\mathrm{t}, J=7.1 \mathrm{~Hz}, 3 \mathrm{H}) ;{ }^{13} \mathrm{C} \mathrm{NMR}$ $\left(100 \mathrm{MHz}, \mathrm{CDCl}_{3}\right): \delta 187.7,186.6,145.1,138.7,138.0,132.7,131.1$, 129.0, 128.4, 121.0, 120.8, 110.8, 100.0, 42.1, 23.8, 13.7; HRMS (ESI) for $\mathrm{C}_{19} \mathrm{H}_{15} \mathrm{NO}_{2}[\mathrm{M}+\mathrm{H}]^{+}$: calcd, 290.1181; found, 290.1176 .

4.3.15. 9-Isopropyl-3-methyl-1aH-oxireno $\left[2^{\prime}, 3^{\prime}: 4,5\right]$ benzo[1,2-a]carbazole-2,10(9H,10aH)-dione (8a). Starting from $\mathbf{8 b}$ (crude, 55 $\mathrm{mg}, 0.18 \mathrm{mmol}$ ), 8a (48 $\mathrm{mg}, 84 \%)$ was isolated as a yellow solid: $\mathrm{mp}$ 177-179 ${ }^{\circ} \mathrm{C}$; FT-IR $\left(\nu_{\max } \mathrm{cm}^{-1}\right): 1680,1264,1202,1192,1031 ;{ }^{1} \mathrm{H}$ $\operatorname{NMR}\left(400 \mathrm{MHz}, \mathrm{CDCl}_{3}\right): \delta 8.10(\mathrm{~s}, 1 \mathrm{H}), 8.06(\mathrm{~d}, J=7.8 \mathrm{~Hz}, 1 \mathrm{H})$, $7.69(\mathrm{~d}, J=8.5 \mathrm{~Hz}, 1 \mathrm{H}), 7.49(\mathrm{dt}, J=6.8,0.9 \mathrm{~Hz}, 1 \mathrm{H}), 7.27(\mathrm{~d}, J=$ $7.4 \mathrm{~Hz}, 1 \mathrm{H}), 4.55-4.66(\mathrm{~m}, 1 \mathrm{H}), 4.12(\mathrm{ABq}, J=9.5 \mathrm{~Hz}, 2 \mathrm{H}), 2.72(\mathrm{~s}$, $3 \mathrm{H}), 1.92(\mathrm{~d}, J=6.8 \mathrm{~Hz}, 3 \mathrm{H}), 1.38(\mathrm{~d}, J=7.0 \mathrm{~Hz}, 3 \mathrm{H}) ;{ }^{13} \mathrm{C} \mathrm{NMR}$ $\left(100 \mathrm{MHz}, \mathrm{CDCl}_{3}\right): \delta 194.9,193.0,142.5,137.6,130.9,129.9,128.1$, $127.7,123.1,121.2,120.4,118.6,113.8,56.6,54.5,51.1,22.1,20.7$, 20.3; Elemental analysis for $\mathrm{C}_{20} \mathrm{H}_{17} \mathrm{NO}_{3}$ calcd: $\mathrm{C}, 75.22 ; \mathrm{H}, 5.37$; , 4.39. Found: $\mathrm{C}, 75.55 ; \mathrm{H}, 5.16$; N, 4.03; HRMS (ESI) for $\mathrm{C}_{20} \mathrm{H}_{17} \mathrm{NO}_{3}$ $[\mathrm{M}+\mathrm{H}]^{+}$: calcd, 320.1281; found, 320.1286 .

4.3.16. 3-Ethyl-9-isopropyl-1aH-oxireno $\left[2^{\prime}, 3^{\prime}: 4,5\right]$ benzo[1,2-a]carbazole-2,10(9H,10aH)-dione (9a). Starting from $9 \mathbf{b}(250 \mathrm{mg}$, $0.79 \mathrm{mmol}), 9 \mathrm{a}(200 \mathrm{mg}, 76 \%)$ was isolated as a yellow solid. FT-IR $\left(\nu_{\max }, \mathrm{cm}^{-1}\right): 1741,1725,1706,1679,1647,1626,1547,1532,1516$, $1478,1464,1426,1395,1367,1310,1200 ;{ }^{1} \mathrm{H}$ NMR $(400 \mathrm{MHz}$, $\left.\mathrm{CDCl}_{3}\right): \delta 8.18(\mathrm{~s}, 1 \mathrm{H}), 8.11(\mathrm{~d}, J=7.8 \mathrm{~Hz}, 1 \mathrm{H}), 7.71(\mathrm{~d}, J=8.4 \mathrm{~Hz}$, $1 \mathrm{H}), 7.51(\mathrm{t}, J=7.6 \mathrm{~Hz}, 1 \mathrm{H}), 7.28(\mathrm{t}, J=7.6 \mathrm{~Hz}, 1 \mathrm{H}), 4.63(\mathrm{~h}, J=6.9$ $\mathrm{Hz}, 1 \mathrm{H}), 4.16(\mathrm{~d}, J=4.6 \mathrm{~Hz}, 1 \mathrm{H}), 4.15(\mathrm{~d}, J=4 \mathrm{~Hz}, 1 \mathrm{H}), 3.21-3.03$ $(\mathrm{m}, 2 \mathrm{H}), 1.94(\mathrm{~d}, J=6.9 \mathrm{~Hz}, 3 \mathrm{H}), 1.42(\mathrm{~d}, J=7 \mathrm{~Hz}, 3 \mathrm{H}), 1.34(\mathrm{t}, J=$ $7.4 \mathrm{~Hz}, 3 \mathrm{H}) ;{ }^{13} \mathrm{C}$ NMR $\left(100 \mathrm{MHz}, \mathrm{CDCl}_{3}\right): \delta 195.1,193.0,142.5$, 137.5, 137.2, 130.0, 127.7, 126.7, 123.2, 121.2, 120.4, 118.7, 113.8, 56.5, 54.4, 51.1, 27.5, 20.7, 20.3, 16.4; HRMS (ESI) for $\mathrm{C}_{21} \mathrm{H}_{19} \mathrm{O}_{3} \mathrm{~N}$ $[\mathrm{M}+\mathrm{H}]^{+}$: calcd, 334.1443; found, 334.1445.

4.3.17. 5-Ethyl-11-isopropyl-1H-benzo[a]carbazole-1,4(11H)dione $(\mathbf{9 b})$. Starting from $N$-isopropyl-3-(but-1-en-1-yl)-indole (1.02 $\mathrm{g}, 4.8 \mathrm{mmol}$ ), compound $\mathbf{9 b}$ was isolated as a dark red-brown solid (261 mg, 13\%). FT-IR $\left(\nu_{\max } \mathrm{cm}^{-1}\right)$ : 1741, 1693, 1651, 1617, 1589, $1534,1463,1428,1391,1368,1308,1282,1233,1199,1156,1105$, $1062 ;{ }^{1} \mathrm{H}$ NMR $\left(400 \mathrm{MHz}, \mathrm{CDCl}_{3}\right): \delta 8.10(\mathrm{~s}, 1 \mathrm{H}), 8.10(\mathrm{~d}, J=7.6$ $\mathrm{Hz}, 1 \mathrm{H}), 7.74(\mathrm{~d}, J=8.6 \mathrm{~Hz}, 1 \mathrm{H}), 7.5(\mathrm{td}, J=7.2 \mathrm{~Hz}, 1.2 \mathrm{~Hz}, 1 \mathrm{H})$, $7.28(\mathrm{td}, J=7.8 \mathrm{~Hz}, 0.7 \mathrm{~Hz}, 1 \mathrm{H}), 6.87(\mathrm{dd}, J=17.4 \mathrm{~Hz}, 10.1 \mathrm{~Hz}, 2 \mathrm{H})$, $4.74(\mathrm{~h}, J=7 \mathrm{~Hz}, 1 \mathrm{H}), 3.26(\mathrm{q}, J=7.4 \mathrm{~Hz}, 2 \mathrm{H}), 1.67(\mathrm{~d}, J=6.9 \mathrm{~Hz}$

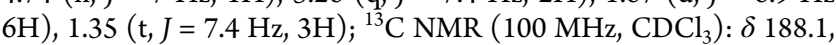
$186.9,143.7,139.8,139.2,138.8,137.7,131.2,129.1,127.8,127.5$, 123.6, 121.2, 120.7, 120.1, 114.4, 52.5, 28.9, 21.1, 15.7; HRMS (ESI) for $\mathrm{C}_{21} \mathrm{H}_{19} \mathrm{O}_{2} \mathrm{~N}[\mathrm{M}+\mathrm{H}]^{+}$: calcd, 318.1494; found, 318.1501.

4.3.18. 9-Isopropyl-10a-phenyl-1a,10a-dihydro-2H-oxireno$\left[2^{\prime}, 3^{\prime}: 4,5\right]$ benzo $[1,2-a]$ carbazole-2,10(9H)-dione (10a). Starting from $10 \mathrm{~b}, 11 \mathbf{b}(40 \mathrm{mg}, 0.105 \mathrm{mmol})$, the mixture of regioisomers, was isolated as a yellow solid (30 mg, 73\%). Using reversed-phase semi-preparative HPLC, compound 10a was isolated as an orangeyellow solid: FT-IR $\left(\nu_{\max } \mathrm{cm}^{-1}\right): 1679,1617,1553,1455,1416,1376$, $1323,1286,1221,1167,1128,1078,1021 ;{ }^{1} \mathrm{H}$ NMR $(400 \mathrm{MHz}$, $\left.\mathrm{CDCl}_{3}\right): \delta 8.36(\mathrm{~d}, J=8.0 \mathrm{~Hz}, 1 \mathrm{H}), 8.15(\mathrm{~d}, J=8.0 \mathrm{~Hz}, 1 \mathrm{H}), 7.92(\mathrm{~d}$, $J=7.9 \mathrm{~Hz}, 1 \mathrm{H}), 7.74(\mathrm{~d}, J=8.3 \mathrm{~Hz}, 1 \mathrm{H}), 7.63-7.59(\mathrm{~m}, 2 \mathrm{H}), 7.55-$ $7.47(\mathrm{~m}, 4 \mathrm{H}), 7.34-7.29(\mathrm{~m}, 1 \mathrm{H}), 4.61(\mathrm{~h}, J=7.0 \mathrm{~Hz}, 1 \mathrm{H}), 4.06(\mathrm{~s}$, $1 \mathrm{H}), 1.90(\mathrm{~d}, J=4 \mathrm{~Hz}, 3 \mathrm{H}), 1.40(\mathrm{~d}, J=4 \mathrm{~Hz}, 3 \mathrm{H}) ;{ }^{13} \mathrm{C}$ NMR $(100$ $\left.\mathrm{MHz}, \mathrm{CDCl}_{3}\right): \delta 192.7,191.4,142.2,139.0,131.1,129.9,129.4$, $128.7,128.3,128.2,127.7,124.8,123.5,121.3,120.7,119.0,118.0$, 114.0, 63.9, 63.4, 51.4, 20.8, 20.6; HRMS (ESI) for $\mathrm{C}_{25} \mathrm{H}_{19} \mathrm{O}_{3} \mathrm{~N}[\mathrm{M}+$ $\mathrm{H}]^{+}$: calcd, 382.1443; found, 382.1443 .

4.3.19. 11-Isopropyl-3-phenyl-1H-benzo[a]carbazole-1,4(11H)dione + 11-Isopropyl-2-phenyl-1H-benzo[a]carbazole-1,4(11H)dione $(10 b, 11 b)$. Starting from 3 -vinyl, $N$-isopropyl-indole (250 $\mathrm{mg}, 1.35 \mathrm{mmol}), \mathbf{1 0 b}, \mathbf{1 1 b}$ mixture were isolated as a dark red-brown solid $(100 \mathrm{mg}, 20 \%)$; FT-IR $\left(\nu_{\max } \mathrm{cm}^{-1}\right): 1643,1590,1469,1418$, 1294, 1180, 1139, 1099, 1044; ${ }^{1} \mathrm{H}$ NMR (400 MHz, $\left.\mathrm{CDCl}_{3}\right): \delta 8.34$ $(\mathrm{d}, J=7.9 \mathrm{~Hz}, 1 \mathrm{H}), 8.13(\mathrm{dd}, J=7.9,2.8 \mathrm{~Hz}, 2 \mathrm{H}), 7.79(\mathrm{~d}, J=8.3 \mathrm{~Hz}$ $1 \mathrm{H}), 7.63(\mathrm{dd}, J=6.6,2.9 \mathrm{~Hz}, 2 \mathrm{H}), 7.60-7.43(\mathrm{~m}, 7 \mathrm{H}), 7.32(\mathrm{t}, J=$ $7.5 \mathrm{~Hz}, 1 \mathrm{H}), 7.07(\mathrm{~s}, 1 \mathrm{H}), 5.09(\mathrm{~h}, J=7.0 \mathrm{~Hz}, 1 \mathrm{H}), 1.73(\mathrm{~d}, J=7.0$ $\mathrm{Hz}, 6 \mathrm{H}) ;{ }^{13} \mathrm{C}$ NMR $\left(100 \mathrm{MHz}, \mathrm{CDCl}_{3}\right): \delta 187.8,186.8,146.1,137.2$, $136.4,132.8,130.3,129.5,129.4,128.7,124.8,121.2,120.8,118.3$, 
114.3, 64.3, 52.4, 21.2; HRMS (ESI) for $\mathrm{C}_{25} \mathrm{H}_{19} \mathrm{O}_{2} \mathrm{~N}[\mathrm{M}+\mathrm{H}]^{+}$: calcd, 366.1494; found, 366.1493 .

4.3.20. 9-Isopropyl-1a-phenyl-1a,10a-dihydro-2H-oxireno$\left[2^{\prime}, 3^{\prime}: 4,5\right]$ benzo[1,2-a]carbazole-2,10(9H)-dione (11a). Starting from $10 \mathrm{~b}, 11 \mathrm{~b}(40 \mathrm{mg}, 0.105 \mathrm{mmol})$, the mixture of regioisomers, was isolated as a yellow solid (30 mg, 73\%). Using reversed-phase semi-preparative HPLC, compound 11a was isolated as a yellow solid: FT-IR $\left(\nu_{\max } \mathrm{cm}^{-1}\right): 1676,1559,1455,1423,1297,1257,1213,1131$, 1102, 1064, 1028; ${ }^{1} \mathrm{H}$ NMR (400 MHz, $\left.\mathrm{CDCl}_{3}\right): \delta 8.34(\mathrm{~d}, J=8 \mathrm{~Hz}$, $1 \mathrm{H}), 8.14(\mathrm{~d}, J=8 \mathrm{~Hz}, 1 \mathrm{H}), 8.00(\mathrm{~d}, J=8.0 \mathrm{~Hz}, 1 \mathrm{H}), 7.77(\mathrm{~d}, J=8$ $\mathrm{Hz}, 1 \mathrm{H}), 7.58-7.52(\mathrm{~m}, 3 \mathrm{H}), 7.49-7.45(\mathrm{~m}, 3 \mathrm{H}), 7.33(\mathrm{t}, J=7.5 \mathrm{~Hz}$, $1 \mathrm{H}), 4.81(\mathrm{~h}, J=6.9 \mathrm{~Hz}, 1 \mathrm{H}), 4.09(\mathrm{~s}, 1 \mathrm{H}), 2.00(\mathrm{~d}, J=6.9 \mathrm{~Hz}, 3 \mathrm{H})$, $1.46(\mathrm{~d}, J=7.0 \mathrm{~Hz}, 3 \mathrm{H}) .{ }^{13} \mathrm{C}$ NMR $\left(100 \mathrm{MHz}, \mathrm{CDCl}_{3}\right): \delta 193.2$, 190.7, 142.2, 138.4, 131.3, 130.9, 130.8, 129.4, 128.6, 127.9, 127.7, 125.0, 123.4, 121.3, 120.7, 119.1, 118.2, 113.9, 65.8, 62.3, 51.3, 20.8, 20.6; HRMS (ESI) for $\mathrm{C}_{25} \mathrm{H}_{19} \mathrm{O}_{3} \mathrm{~N}[\mathrm{M}+\mathrm{H}]^{+}$: calculated, 382.1443; found, 382.1443 .

4.3.21. 9-Isopropyl-10a-(4-methoxyphenyl)-1a,10a-dihydro-2Hoxireno $\left[2^{\prime}, 3^{\prime}: 4,5\right]$ benzo $[1,2$-a]carbazole-2, $10(9 H)$-dione $(12 a)$. Starting from 12b, 13b $(244 \mathrm{mg}, 0.592 \mathrm{mmol})$, the mixture of regioisomers, was isolated as a yellow solid (91 mg, 36\%). Using reversed-phase semi-preparative HPLC, compound 12a was isolated as a yellow solid: FT-IR $\left(\nu_{\max } \mathrm{cm}^{-1}\right): 1687,1601,1514,1456,1424$, $1385,1332,1292,1245,1168,1134,1024 ;{ }^{1} \mathrm{H}$ NMR $(400 \mathrm{MHz}$, $\left.\mathrm{CDCl}_{3}\right): \delta 8.35(\mathrm{~d}, J=7.9 \mathrm{~Hz}, 1 \mathrm{H}), 8.14(\mathrm{~d}, J=7.7 \mathrm{~Hz}, 1 \mathrm{H}), 7.91(\mathrm{~d}$, $J=8.1 \mathrm{~Hz}, 1 \mathrm{H}), 7.74(\mathrm{~d}, J=8.5 \mathrm{~Hz}, 1 \mathrm{H}), 7.56-7.50(\mathrm{~m}, 3 \mathrm{H}), 7.31(\mathrm{t}$, $J=7.6 \mathrm{~Hz}, 1 \mathrm{H}), 7.04-7.00(\mathrm{~m}, 2 \mathrm{H}), 4.61(\mathrm{~h}, J=6.9 \mathrm{~Hz}, 1 \mathrm{H}), 4.05(\mathrm{~s}$, $1 \mathrm{H}), 3.87(\mathrm{~s}, 3 \mathrm{H}), 1.91(\mathrm{~d}, J=6.9 \mathrm{~Hz}, 3 \mathrm{H}), 1.42-1.39(\mathrm{~m}, 3 \mathrm{H}) ;{ }^{13} \mathrm{C}$ NMR $\left(100 \mathrm{MHz}, \mathrm{CDCl}_{3}\right): \delta 193.2,191.7,160.4,142.2,139.0,131.1$, $129.9,129.6,127.7,124.8,123.5,122.9,121.3,120.6,118.0,114.1$, 114.0, 64.0, 55.5, 51.4, 20.8, 20.6; HRMS (ESI) for $\mathrm{C}_{26} \mathrm{H}_{21} \mathrm{O}_{4} \mathrm{~N}[\mathrm{M}+$ $\mathrm{H}]^{+}$: calcd, 412.1549; found, 412.1546 .

4.3.22. 11-Isopropyl-3-(4-methoxyphenyl)-1H-benzo[a]carbazole-1,4(11H)-dione + 11-Isopropyl-2-(4-methoxyphenyl)$1 \mathrm{H}$-benzo[a]carbazole-1,4(11H)-dione $(12 \mathrm{~b}, 13 \mathrm{~b})$. Starting from 3vinyl, $N$-isopropyl-indole (190.2 mg, $1.03 \mathrm{mmol}), \mathbf{1 2 b}, \mathbf{1 3 b}$ mixture was isolated as a dark red-brown solid $(210.2 \mathrm{mg}, 52 \%)$; FT-IR $\left(\nu_{\max }\right.$ $\left.\mathrm{cm}^{-1}\right): 1648,1602,1556,1511,1462,1417,1366,1298,1230,1178$, $1134,1086,1031 ;{ }^{1} \mathrm{H}$ NMR $\left(400 \mathrm{MHz}, \mathrm{CDCl}_{3}\right): \delta 8.33(\mathrm{~d}, J=7.9$ $\mathrm{Hz}, 1 \mathrm{H}), 8.13-8.04(\mathrm{~m}, 2 \mathrm{H}), 7.88(\mathrm{~d}, J=8.4 \mathrm{~Hz}, 1 \mathrm{H}), 7.63(\mathrm{~d}, J=$ $6.9 \mathrm{~Hz}, 2 \mathrm{H}), 7.52(\mathrm{t}, J=7.4 \mathrm{~Hz}, 1 \mathrm{H}), 7.30(\mathrm{t}, J=7.4 \mathrm{~Hz}, 1 \mathrm{H}), 7.05-$ $7.00(\mathrm{~m}, 3 \mathrm{H}), 5.0(\mathrm{~h}, J=7.0 \mathrm{~Hz}, 1 \mathrm{H}), 3.88(\mathrm{~s}, 3 \mathrm{H}), 1.74(\mathrm{~d}, J=7 \mathrm{~Hz}$, $6 \mathrm{H})$ (regioisomer ratio $4: 1) ;{ }^{13} \mathrm{C} \mathrm{NMR}\left(100 \mathrm{MHz}, \mathrm{CDCl}_{3}\right): \delta 186.3$, $185.4,161.2,145.6,143.0,139.4,134.9,132.3,131.2,131.0,127.6$, $125.8,124.7,123.8,121.2,120.8,119.4,118.7,114.4,114.3,114.1$, 55.5, 52.3, 21.3; MALDI-TOF for $\mathrm{C}_{26} \mathrm{H}_{21} \mathrm{O}_{3} \mathrm{~N}$ : expected mass, 395.4498; found, 395.0778.

4.3.23. 9-Isopropyl-1a-(4-methoxyphenyl)-1a,10a-dihydro-2Hoxireno[2', $\left.3^{\prime}: 4,5\right]$ benzo[1,2-a]carbazole-2,10(9H)-dione (13a). Starting from 12b, 13b (244 mg, $0.592 \mathrm{mmol})$, the mixture of regioisomers, was isolated as a yellow solid (91 mg, 36\%). Using reversed-phase semi-preparative HPLC, compound 13a was isolated as a yellow solid: FT-IR $\left(\nu_{\max } \mathrm{cm}^{-1}\right): 1682,1606,1513,1454,1425$, $1379,1293,1245,1169,1026 ;{ }^{1} \mathrm{H}$ NMR $\left(400 \mathrm{MHz}, \mathrm{CDCl}_{3}\right): \delta 8.34$ $(\mathrm{d}, J=7.9 \mathrm{~Hz}, 1 \mathrm{H}), 8.14(\mathrm{~d}, J=7.8 \mathrm{~Hz}, 1 \mathrm{H}), 8.00(\mathrm{~d}, J=8.1 \mathrm{~Hz}, 1 \mathrm{H})$, 7.77 (d, $J=8.3 \mathrm{~Hz}, 1 \mathrm{H}), 7.54$ (ddd, $J=8.5,7.3,1.3 \mathrm{~Hz}, 1 \mathrm{H}$ ), 7.50$7.47(\mathrm{~m}, 2 \mathrm{H}), 7.35-7.30(\mathrm{~m}, 1 \mathrm{H}), 7.02-6.98(\mathrm{~m}, 2 \mathrm{H}), 4.80(\mathrm{~h}, J=$ $6.9 \mathrm{~Hz}, 1 \mathrm{H}), 4.09(\mathrm{~s}, 1 \mathrm{H}), 3.86(\mathrm{~s}, 3 \mathrm{H}), 2.00(\mathrm{~d}, J=6.9 \mathrm{~Hz}, 3 \mathrm{H}), 1.46$ $(\mathrm{d}, J=7.0 \mathrm{~Hz}, 3 \mathrm{H}) ;{ }^{13} \mathrm{C}$ NMR $\left(100 \mathrm{MHz}, \mathrm{CDCl}_{3}\right): \delta 199.0,198.6$, 198.0, 194.1, 189.2, 173.1, 159.4, 140.8, 137.1, 130.2, 128.3, 128.1, $127.8,126.2,123.7,121.4,121.3,121.2,120.9,118.8,114.7,114.6$, $114.3,114.1,113.9,113.7,84.6,60.1,55.4,55.4,51.4,51.2,29.9,21.5$, 20.9, 20.5; HRMS (ESI) for $\mathrm{C}_{26} \mathrm{H}_{21} \mathrm{O}_{4} \mathrm{~N}[\mathrm{M}+\mathrm{H}]^{+}$: calcd, 412.1549; found, 412.1546 .

4.3.24. 10a-(4-Bromophenyl)-9-isopropyl-1a,10a-dihydro-2Hoxireno $\left[2^{\prime}, 3^{\prime}: 4,5\right]$ benzo[1,2-a]carbazole-2,10(9H)-dione (14a). Starting from $14 \mathrm{~b}, 15 \mathrm{~b}(627.2 \mathrm{mg}, 1.41 \mathrm{mmol})$, the mixture of regioisomers, was isolated as a yellow solid $(604.5 \mathrm{mg}, 93 \%)$. Using reversed-phase semi-preparative HPLC, compound 14a was isolated as a yellow solid: FT-IR $\left(\nu_{\max } \mathrm{cm}^{-1}\right): 1741,1725,1678,1648,1616$,
$1549,1516,1498,1463,1422,1396,1366,1299,1223,1167,1133$, 1107; ${ }^{1} \mathrm{H}$ NMR ( $400 \mathrm{MHz}, \mathrm{CDCl}_{3}$ ): $\delta 8.35(\mathrm{~d}, J=8.1 \mathrm{~Hz}, 1 \mathrm{H}), 8.14$ $(\mathrm{d}, J=7.8 \mathrm{~Hz}, 1 \mathrm{H}), 7.91(\mathrm{~d}, J=7.8 \mathrm{~Hz}, 1 \mathrm{H}), 7.74(\mathrm{~d}, J=8.3 \mathrm{~Hz}, 1 \mathrm{H})$, 7.65-7.61 (m, 2H), 7.57-7.46 (m, 3H), 7.35-7.29 (m, 1H), $4.57(\mathrm{~h}$, $J=7.0 \mathrm{~Hz}, 1 \mathrm{H}), 4.01(\mathrm{~s}, 1 \mathrm{H}), 1.90(\mathrm{~d}, J=6.9 \mathrm{~Hz}, 3 \mathrm{H}), 1.40(\mathrm{~d}, J=$ $7.0 \mathrm{~Hz}, 3 \mathrm{H}) ;{ }^{13} \mathrm{C}$ NMR $\left(100 \mathrm{MHz}, \mathrm{CDCl}_{3}\right): \delta 192.1,190.1,142.2$, $139.1,131.8,131.0,131.3,130.0,129.8,127.8,125.0,123.7,123.4$, $121.3,120.7,118.6,118.1,114.0,64.0,62.9,51.5,22.2,20.8,20.6$; HRMS (ESI) for $\mathrm{C}_{25} \mathrm{H}_{18} \mathrm{O}_{3} \mathrm{NBr}[\mathrm{M}+\mathrm{H}]^{+}$: calcd, 460.0548; found, 460.0548 .

4.3.25. 3-(4-Bromophenyl)-11-isopropyl-1H-benzo[a]carbazole1,4(11H)-dione + 2-(4-Bromophenyl)-11-isopropyl-1H-benzo[a]carbazole-1,4(11H)-dione (14b, 15b). Starting from 3-vinyl, $N$ isopropyl-indole ( $400 \mathrm{mg}, 2.16 \mathrm{mmol}$ ), 14b, 15b mixture was isolated as a dark red-brown solid $(653.1 \mathrm{mg}, 68 \%)$; FT-IR $\left(\nu_{\max } \mathrm{cm}^{-1}\right): 1741$, $1725,1707,1694,1678,1646,1615,1547,1532,1516,1485,1463$, $1425,1396,1366,1340,1311,1227,1134 ;{ }^{1} \mathrm{H}$ NMR $(400 \mathrm{MHz}$, $\left.\mathrm{CDCl}_{3}\right): \delta 8.33(\mathrm{~d}, J=7.9 \mathrm{~Hz}, 1 \mathrm{H}), 8.14-8.04(\mathrm{~m}, 2 \mathrm{H}), 7.88(\mathrm{~d}, J=$ $3.6 \mathrm{~Hz}, 1 \mathrm{H}), 7.66-7.61(\mathrm{~m}, 2 \mathrm{H}), 7.55-7.50(\mathrm{~m}, 3 \mathrm{H}), 7.32(\mathrm{t}, J=7.5$ $\mathrm{Hz}, 1 \mathrm{H}), 7.04(\mathrm{~d}, J=9.0 \mathrm{~Hz}, 1 \mathrm{H}), 5.08(\mathrm{~h}, J=7.0 \mathrm{~Hz}, 1 \mathrm{H}), 1.73(\mathrm{~s}$, $6 \mathrm{H})$ (regioisomer ratio: $1.22: 1) ;{ }^{13} \mathrm{C} \mathrm{NMR}\left(100 \mathrm{MHz}^{13} \mathrm{CDCl}_{3}\right): \delta$ 186.0, 185.9, 185.7, 184.7, 148.2, 145.1, 143.0, 142.8, 139.8, 139.4, $136.4,133.3,133.0,132.4,132.0,131.8,131.6,131.5,131.1,131.0$, $127.7,125.0,124.8,124.6,123.8,121.3,120.9,119.5,119.4,118.4$, 118.4, 114.4, 114.4, 52.4, 52.3, 21.3, 21.2; HRMS (ESI) for $\mathrm{C}_{25} \mathrm{H}_{18} \mathrm{O}_{2} \mathrm{NBr}[\mathrm{M}+\mathrm{H}]^{+}$: calcd, 444.0599; found, 444.0600.

4.3.26. 1a-(4-Bromophenyl)-9-isopropyl-1a,10a-dihydro-2Hoxireno $\left[2^{\prime}, 3^{\prime}: 4,5\right]$ benzo[1,2-a]carbazole-2,10(9H)-dione (15a). Starting from $14 \mathrm{~b}, 15 \mathrm{~b}(627.2 \mathrm{mg}, 1.41 \mathrm{mmol})$, the mixture of regioisomers, was isolated as a yellow solid (604.5 mg, 93\%). Using reversed-phase semi-preparative HPLC, compound 15a was isolated as a yellow solid: FT-IR $\left(\nu_{\max } \mathrm{cm}^{-1}\right): 1680,1556,1460,1417,1367$, $1311,1219,1136,1106,1064,1011 ;{ }^{1} \mathrm{H}$ NMR $\left(400 \mathrm{MHz}, \mathrm{CDCl}_{3}\right): \delta$ $8.33(\mathrm{~d}, J=7.9 \mathrm{~Hz}, 1 \mathrm{H}), 8.14(\mathrm{~d}, J=7.8 \mathrm{~Hz}, 1 \mathrm{H}), 7.99(\mathrm{~d}, J=8.1 \mathrm{~Hz}$, $1 \mathrm{H}), 7.77(\mathrm{~d}, J=8.5 \mathrm{~Hz}, 1 \mathrm{H}), 7.63-7.59(\mathrm{~m}, 2 \mathrm{H}), 7.55(\mathrm{ddd}, J=8.4$, 7.4, $1.2 \mathrm{~Hz}, 1 \mathrm{H}), 7.46-7.41(\mathrm{~m}, 2 \mathrm{H}), 7.33(\mathrm{t}, J=7.6 \mathrm{~Hz}, 1 \mathrm{H}), 4.78$ $(\mathrm{h}, J=6.9 \mathrm{~Hz}, 1 \mathrm{H}), 4.05(\mathrm{~s}, 1 \mathrm{H}), 2.00(\mathrm{~d}, J=6.9 \mathrm{~Hz}, 3 \mathrm{H}), 1.45(\mathrm{~d}, J=$ $7.0 \mathrm{~Hz}, 3 \mathrm{H}) ;{ }^{13} \mathrm{C}$ NMR $\left(100 \mathrm{MHz}, \mathrm{CDCl}_{3}\right): \delta 192.7,190.3,142.2$, $138.5,131.8,130.9,130.6,130.4,129.6,127.8,125.1,123.8,123.4$, 121.3, 120.8, 119.2, 118.0, 114.0, 65.3, 62.3, 51.3, 20.8, 20.6; HRMS (ESI) for $\mathrm{C}_{25} \mathrm{H}_{18} \mathrm{O}_{3} \mathrm{NBr}[\mathrm{M}+\mathrm{H}]^{+}$: calcd, 460.0548 ; found, 460.0548 .

4.3.27. 9-(Pent-4-yn-1-yl)-1a,10a-dihydro-2H-oxireno[ $\left.2^{\prime}, 3^{\prime}: 4,5\right]$ benzo[1,2-a]carbazole-2,10(9H)-dione (P1). Starting from Q1 (150 $\mathrm{mg}, 0.479 \mathrm{mmol}), \mathbf{P 1}$ was isolated as a bright yellow solid $(73 \mathrm{mg}$, $46 \%)$. FT-IR $\left(\nu_{\max } \mathrm{cm}^{-1}\right): 3291,2924,2855,1687,1564,1468,1425$, $1334,1287,1216,1183,865,742 ;{ }^{1} \mathrm{H}$ NMR $\left(400 \mathrm{MHz} \mathrm{CDCl}_{3}\right): \delta$ $8.36(\mathrm{~d}, J=8.0 \mathrm{~Hz}, 1 \mathrm{H}), 8.10(\mathrm{~d}, J=7.7 \mathrm{~Hz}, 1 \mathrm{H}), 7.88(\mathrm{~d}, J=8.0 \mathrm{~Hz}$, $1 \mathrm{H}), 7.60(\mathrm{t}, J=6.0 \mathrm{~Hz}, 2 \mathrm{H}), 7.35-7.32(\mathrm{~m}, 1 \mathrm{H}), 4.68-4.61(\mathrm{~m}$, $1 \mathrm{H}), 4.57-4.49(\mathrm{~m}, 1 \mathrm{H}), 4.14(\mathrm{dd}, J=6.5,4.2 \mathrm{~Hz}, 2 \mathrm{H}), 2.18-2.01$ $(\mathrm{m}, 3 \mathrm{H}), 1.97-1.88(\mathrm{~m}, 2 \mathrm{H}) ;{ }^{13} \mathrm{C}$ NMR $\left(100 \mathrm{MHz}, \mathrm{CDCl}_{3}\right): \delta 192.5$, $191.4,143.9,136.9,131.3,130.2,128.6,125.4,121.8,121.1,121.0$, 118.4, 117.7, 110.6, 83.2, 69.7, 56.1, 54.8, 44.4, 26.6, 16.0.; HRMS (ESI): for $\mathrm{C}_{21} \mathrm{H}_{15} \mathrm{NO}_{3}[\mathrm{M}+\mathrm{H}]^{+}$: calcd, 330.1130; found, 330.1131.

4.3.28. 9-(Pent-4-yn-1-yl)-1a-phenyl-1a,10a-dihydro-2Hoxireno $\left[2^{\prime}, 3^{\prime}: 4,5\right]$ benzo[1,2-a]carbazole-2,10(9H)-dione (P2). Starting from Q2 (crude, $116 \mathrm{mg}, 0.152 \mathrm{mmol}$ ), $\mathbf{P 2}$ was isolated as a bright yellow solid $(85 \mathrm{mg}, 70 \%)$. FT-IR $\left(\nu_{\max } \mathrm{cm}^{-1}\right): 2922,2861,1687$, $1465,1335,1287,1205,1126,1066,739 ;{ }^{1} \mathrm{H}$ NMR $(400 \mathrm{MHz}$, $\left.\mathrm{CDCl}_{3}\right): \delta 8.34(\mathrm{~d}, J=8.2 \mathrm{~Hz}, 1 \mathrm{H}), 8.11(\mathrm{~d}, J=7.8 \mathrm{~Hz}, 1 \mathrm{H}), 7.97(\mathrm{~d}$, $J=7.9 \mathrm{~Hz}, 1 \mathrm{H}), 7.62-7.56(\mathrm{~m}, 4 \mathrm{H}), 7.49-7.46(\mathrm{~m}, 3 \mathrm{H}), 7.37-7.33$ $(\mathrm{m}, 1 \mathrm{H}), 4.74-4.68(\mathrm{~m}, 1 \mathrm{H}), 4.60-4.52(\mathrm{~m}, 1 \mathrm{H}), 4.10(\mathrm{~s}, 1 \mathrm{H})$, $2.18-2.08(\mathrm{~m}, 2 \mathrm{H}), 2.06(\mathrm{t}, J=2.2 \mathrm{~Hz}, 1 \mathrm{H}), 1.98-1.90(\mathrm{~m}, 2 \mathrm{H}) .{ }^{13} \mathrm{C}$ NMR (100 MHz, $\left.\mathrm{CDCl}_{3}\right): \delta 192.4,191.0,143.9,136.7,131.1,131.0$, $131.0,129.4,128.6,128.5,127.9,125.3,121.9,121.1,121.0,119.1$, $117.9,110.6,83.2,69.7,65.5,62.4,44.4,26.7,16.0$.; HRMS (ESI): for $\mathrm{C}_{27} \mathrm{H}_{19} \mathrm{NO}_{3}[\mathrm{M}+\mathrm{H}]^{+}$: calcd, 406.1443; found, 406.1443 .

4.3.29. 11-(Pent-4-yn-1-yl)-1H-benzo[a]carbazole-1,4(11H)dione (Q1). Starting from $N$-(pent-4-yn-1-yl)-indole-3-carboxaldehyde (1 g, $4.66 \mathrm{mmol}), \mathbf{Q} 1$ was isolated as a dark red-brown solid $(264 \mathrm{mg}, 27 \%)$. FT-IR $\left(\nu_{\max } \mathrm{cm}^{-1}\right): 3280,2922,2857,1658,1615$, 
1465, 1378, 1292, 1182, 1122, 835, 747; ${ }^{1} \mathrm{H}$ NMR (400 MHz, $\left.\mathrm{CDCl}_{3}\right): \delta 8.35(\mathrm{~d}, J=8.0 \mathrm{~Hz}, 1 \mathrm{H}), 8.09(\mathrm{dt}, J=7.8,0.8 \mathrm{~Hz}, 1 \mathrm{H})$, $8.04(\mathrm{~d}, J=8.0 \mathrm{~Hz}, 1 \mathrm{H}), 7.62-7.56(\mathrm{~m}, 2 \mathrm{H}), 7.35-7.31(\mathrm{~m}, 1 \mathrm{H})$, $6.94(\mathrm{dd}, J=15.3,10.1 \mathrm{~Hz}, 2 \mathrm{H}), 4.78(\mathrm{t}, J=7.3 \mathrm{~Hz}, 2 \mathrm{H}), 2.13-2.08$ $(\mathrm{m}, 2 \mathrm{H}), 2.05-2.03(\mathrm{~m}, 1 \mathrm{H}), 2.00(\mathrm{t}, J=2.6 \mathrm{~Hz}, 2 \mathrm{H}) ;{ }^{13} \mathrm{C} \mathrm{NMR}$ $\left(100 \mathrm{MHz}, \mathrm{CDCl}_{3}\right): \delta 186.1,185.6,144.5,140.3,138.1,137.0,131.6$, $131.5,128.5,125.3,122.2,121.2,120.9,118.9,118.5,111.1,83.5$, 69.4, 46.3, 27.8, 16.1; HRMS (ESI) for $\mathrm{C}_{21} \mathrm{H}_{15} \mathrm{NO}_{2}[\mathrm{M}+\mathrm{H}]^{+}$: calcd, 314.1181; found, 314.1178.

\section{ASSOCIATED CONTENT}

\section{(5) Supporting Information}

The Supporting Information is available free of charge on the ACS Publications website at DOI: 10.1021/acs.jmedchem.9b00774.

Preparative procedures, characterization data, and protocols (PDF)

Proteomics data table (XLSX)

Molecular formula strings (CSV)

\section{AUTHOR INFORMATION}

\section{Corresponding Authors}

*E-mail: skchopra007@gmail.com (S.C.).

*E-mail: siddhesh@iiserpune.ac.in (S.K.).

*E-mail: harinath@iiserpune.ac.in (H.C.).

ORCID

Siddhesh S. Kamat: 0000-0001-6132-7574

Harinath Chakrapani: 0000-0002-7267-0906

\section{Present Addresses}

"Department of Chemistry, Indian Institute of Technology, Kanpur, India.

${ }^{\perp}$ Faculty of Pharmaceutical Sciences, University of Iceland, 107 Reykjavik, Iceland.

\section{Notes}

The authors declare no competing financial interest.

The authors will release the atomic coordinates and experimental data upon article publication.

\section{ACKNOWLEDGMENTS}

The authors thank the Department of Biotechnology (DBT), Government of India (BT/PR15848/MED/29/1025/2016 to H.C. and S.C.), a Wellcome Trust DBT India Alliance Intermediate Fellowship (IA/I/15/2/502058 to S.S.K.) and a DST-FIST Infrastructure Development Grant (to IISER Pune Biology) for the financial support for our research. The Council for Scientific and Industrial Research (CSIR) and the Department of Science and Technology-Innovation in Science Pursuit for Inspired Research (DST-INSPIRE) for graduate student fellowships.

\section{ABBREVIATIONS}

AMR, antimicrobial resistance; S. aureus, Staphylococcus aureus; VRSA, vancomycin-resistant Staphylococcus aureus; ABPP, activity-based protein profiling; $\mathrm{p} K_{\mathrm{a}}$, negative log of aciddissociation constant; INDQE, indole-based quinone epoxide; ATCC, American Type Culture Collection; Dap, daptomycin; E. coli, Escherichia coli; K. pneumoniae, Klebsiella pneumonia; E. faecalis, Enterococcus faecalis; P. aeruginosa, Pseudomonas aeruginosa; A. baumanii, Acinetobacter baumanii; PDI, protein disulfide-isomerase; BTK, Bruton's tyrosine kinase; TCI, targeted covalent inhibitors; NQE, naphthoquinone epoxide; ESKAPE, Escherichia coli, Staphylococcus aureus, Klebsiella pneumoniae, Acinetobacter baumannii, Pseudomonas aeruginosa and Enterococcus faecalis; $\mathrm{mBBr}$, monobromobimane; IAM, iodoacetamide; Mar R, multiple antibiotic resistance regulator; NTA, nitrilotriacetic acid

\section{REFERENCES}

(1) Chambers, H. F.; DeLeo, F. R. Waves of resistance: Staphylococcus aureus in the antibiotic era. Nat. Rev. Microbiol. 2009, 7, 629-641.

(2) Kobayashi, S. D.; Musser, J. M.; DeLeo, F. R. Genomic analysis of the emergence of vancomycin-resistant Staphylococcus aureus. mBio 2012, 3, No. e00170.

(3) Walsh, C.; Wencewicz, T. Antibiotics: Challenges, Mechanisms, Opportunities; American Society of Microbiology, 2016.

(4) Evans, M. J.; Cravatt, B. F. Mechanism-based profiling of enzyme families. Chem. Rev. 2006, 106, 3279-3301.

(5) Liu, Y.; Patricelli, M. P.; Cravatt, B. F. Activity-based protein profiling: the serine hydrolases. Proc. Natl. Acad. Sci. U.S.A. 1999, 96, 14694-14699.

(6) Hatzios, S. K.; Abel, S.; Martell, J.; Hubbard, T.; Sasabe, J.; Munera, D.; Clark, L.; Bachovchin, D. A.; Qadri, F.; Ryan, E. T.; Davis, B. M.; Weerapana, E.; Waldor, M. K. Chemoproteomic profiling of host and pathogen enzymes active in cholera. Nat. Chem. Biol. 2016, 12, 268.

(7) Hacker, S. M.; Backus, K. M.; Lazear, M. R.; Forli, S.; Correia, B. E.; Cravatt, B. F. Global profiling of lysine reactivity and ligandability in the human proteome. Nat. Chem. 2017, 9, 1181-1190.

(8) Hoch, D. G.; Abegg, D.; Adibekian, A. Cysteine-reactive probes and their use in chemical proteomics. Chem. Commun. 2018, 54, 4501-4512.

(9) Abo, M.; Bak, D. W.; Weerapana, E. Optimization of caged electrophiles for improved monitoring of cysteine reactivity in living cells. ChemBioChem 2017, 18, 81-84.

(10) Paulsen, C. E.; Carroll, K. S. Cysteine-mediated redox signaling: Chemistry, Biology, and Tools for discovery. Chem. Rev. 2013, 113, $4633-4679$.

(11) Abegg, D.; Frei, R.; Cerato, L.; Prasad Hari, D.; Wang, C.; Waser, J.; Adibekian, A. Proteome-wide profiling of targets of cysteine reactive small molecules by using ethynyl benziodoxolone reagents. Angew. Chem., Int. Ed. 2015, 54, 10852-10857.

(12) Gersch, M.; Kreuzer, J.; Sieber, S. A. Electrophilic natural products and their biological targets. Nat. Prod. Rep. 2012, 29, 659682.

(13) Kunzmann, M. H.; Bach, N. C.; Bauer, B.; Sieber, S. A. $\alpha$ Methylene- $\gamma$-butyrolactones attenuate Staphylococcus aureus virulence by inhibition of transcriptional regulation. Chem. Sci. 2014, 5, 1158.

(14) Mandl, F. A.; Kirsch, V. C.; Ugur, I.; Kunold, E.; Vomacka, J.; Fetzer, C.; Schneider, S.; Richter, K.; Fuchs, T. M.; Antes, I.; Sieber, S. A. Natural-product-inspired aminoepoxybenzoquinones kill members of the Gram-negative pathogen Salmonella by attenuating cellular stress response. Angew. Chem., Int. Ed. 2016, 55, 14852-14857.

(15) Staub, I.; Sieber, S. A. $\beta$-Lactam probes as selective chemicalproteomic tools for the identification and functional characterization of resistance associated enzymes in MRSA. J. Am. Chem. Soc. 2009, 131, 6271-6276.

(16) Staub, I.; Sieber, S. A. $\beta$-Lactams as Selective Chemical Probes for the in Vivo Labeling of Bacterial Enzymes Involved in Cell Wall Biosynthesis, Antibiotic Resistance, and Virulence. J. Am. Chem. Soc. 2008, 130, 13400-13409.

(17) Drechsel, J.; Mandl, F. A.; Sieber, S. A. Chemical probe to monitor the Parkinsonism-associated protein DJ-1 in live cells. ACS Chem. Biol. 2018, 13, 2016-2019.

(18) Dharmaraja, A. T.; Dash, T. K.; Konkimalla, V. B.; Chakrapani, $\mathrm{H}$. Synthesis, thiol-mediated reactive oxygen species generation profiles and anti-proliferative activities of 2,3-epoxy-1,4-naphthoquinones. Med. Chem. Commun. 2012, 3, 219-224. 
(19) Puri, A. W.; Bogyo, M. Applications of small molecule probes in dissecting mechanisms of bacterial virulence and host responses. Biochemistry 2013, 52, 5985-5996.

(20) Welsch, M. E.; Snyder, S. A.; Stockwell, B. R. Privileged scaffolds for library design and drug discovery. Curr. Opin. Chem. Biol. 2010, 14, 347-361.

(21) https://clsi.org/media/1632/m07a10_sample.pdf (accessed June 20, 2019).

(22) Shukla, M.; Soni, I.; Matsuyama, K.; Tran, T.; Tanga, M.; Gong, L.; Chopra, S. Identification and bioevaluation of SRI-12742 as an antimicrobial agent against multidrug-resistant Acinetobacter baumannii. Int. J. Antimicrob. Agents 2018, 52, 22-27.

(23) Cha, R.; Brown, W. J.; Rybak, M. J. Bactericidal activities of daptomycin, quinupristin-dalfopristin, and linezolid against vancomycin-resistant Staphylococcus aureus in an in vitro pharmacodynamic model with simulated endocardial vegetations. Antimicrob. Agents Chemother. 2003, 47, 3960-3963.

(24) Housecroft, C.; Sharpe, A. Inorganic Chemistry, 4th ed.; Prentice Hall: USA, 2012.

(25) Embaby, A. M.; Schoffelen, S.; Kofoed, C.; Meldal, M.; Diness, F. Rational tuning of fluorobenzene probes for cysteine-selective protein modification. Angew. Chem., Int. Ed. 2018, 57, 8022-8026.

(26) Pan, Z.; Scheerens, H.; Li, S.-J.; Schultz, B. E.; Sprengeler, P. A.; Burrill, L. C.; Mendonca, R. V.; Sweeney, M. D.; Scott, K. C. K.; Grothaus, P. G.; Jeffery, D. A.; Spoerke, J. M.; Honigberg, L. A.; Young, P. R.; Dalrymple, S. A.; Palmer, J. T. Discovery of selective irreversible inhibitors for Bruton's tyrosine kinase. ChemMedChem 2007, 2, 58-61.

(27) Lanning, B. R.; Whitby, L. R.; Dix, M. M.; Douhan, J.; Gilbert, A. M.; Hett, E. C.; Johnson, T. O.; Joslyn, C.; Kath, J. C.; Niessen, S.; Roberts, L. R.; Schnute, M. E.; Wang, C.; Hulce, J. J.; Wei, B.; Whiteley, L. O.; Hayward, M. M.; Cravatt, B. F. A road map to evaluate the proteome-wide selectivity of covalent kinase inhibitors. Nat. Chem. Biol. 2014, 10, 760.

(28) Allimuthu, D.; Adams, D. J. 2-Chloropropionamide as a lowreactivity electrophile for irreversible small-molecule probe identification. ACS Chem. Biol. 2017, 12, 2124-2131.

(29) Shindo, N.; Fuchida, H.; Sato, M.; Watari, K.; Shibata, T.; Kuwata, K.; Miura, C.; Okamoto, K.; Hatsuyama, Y.; Tokunaga, K.; Sakamoto, S.; Morimoto, S.; Abe, Y.; Shiroishi, M.; Caaveiro, J. M. M.; Ueda, T.; Tamura, T.; Matsunaga, N.; Nakao, T.; Koyanagi, S.; Ohdo, S.; Yamaguchi, Y.; Hamachi, I.; Ono, M.; Ojida, A. Selective and reversible modification of kinase cysteines with chlorofluoroacetamides. Nat. Chem. Biol. 2019, 15, 250-258.

(30) Sankar, R. K.; Kumbhare, R. S.; Dharmaraja, A. T.; Chakrapani, $\mathrm{H}$. A phenacrylate scaffold for tunable thiol activation and release. Chem. Commun. 2014, 50, 15323-15326.

(31) Serafimova, I. M.; Pufall, M. A.; Krishnan, S.; Duda, K.; Cohen, M. S.; Maglathlin, R. L.; McFarland, J. M.; Miller, R. M.; Frödin, M.; Taunton, J. Reversible targeting of noncatalytic cysteines with chemically tuned electrophiles. Nat. Chem. Biol. 2012, 8, 471-476.

(32) Krishnan, S.; Miller, R. M.; Tian, B.; Mullins, R. D.; Jacobson, M. P.; Taunton, J. Design of reversible, cysteine-targeted Michael acceptors guided by kinetic and computational analysis. J. Am. Chem. Soc. 2014, 136, 12624-12630.

(33) Khodade, V. S.; Sharath Chandra, M.; Banerjee, A.; Lahiri, S.; Pulipeta, M.; Rangarajan, R.; Chakrapani, H. Bioreductively activated reactive oxygen species (ROS) generators as MRSA inhibitors. ACS Med. Chem. Lett. 2014, 5, 777-781.

(34) Kosower, N. S.; Kosower, E. M. Thiol Labeling with Bromobimanes; Methods in Enzymology; Academic Press, 1987; Vol. 143, pp 76-84.

(35) Speers, A. E.; Adam, G. C.; Cravatt, B. F. Activity-based protein profiling in vivo using a copper(I)-catalyzed azide-alkyne [3 + 2] cycloaddition. J. Am. Chem. Soc. 2003, 125, 4686-4687.

(36) Weerapana, E.; Wang, C.; Simon, G. M.; Richter, F.; Khare, S.; Dillon, M. B. D.; Bachovchin, D. A.; Mowen, K.; Baker, D.; Cravatt, B. F. Quantitative reactivity profiling predicts functional cysteines in proteomes. Nature 2010, 468, 790-795.
(37) Backus, K. M.; Correia, B. E.; Lum, K. M.; Forli, S.; Horning, B. D.; González-Páez, G. E.; Chatterjee, S.; Lanning, B. R.; Teijaro, J. R.; Olson, A. J.; Wolan, D. W.; Cravatt, B. F. Proteome-wide covalent ligand discovery in native biological systems. Nature 2016, 534, 570574.

(38) Kelkar, D. S.; Ravikumar, G.; Mehendale, N.; Singh, S.; Joshi, A.; Sharma, A. K.; Mhetre, A.; Rajendran, A.; Chakrapani, H.; Kamat, S. S. A chemical-genetic screen identifies ABHD12 as an oxidizedphosphatidylserine lipase. Nat. Chem. Biol. 2019, 15, 169-178.

(39) Hao, Z.; Lou, H.; Zhu, R.; Zhu, J.; Zhang, D.; Zhao, B. S.; Zeng, S.; Chen, X.; Chan, J.; He, C.; Chen, P. R. The multiple antibiotic resistance regulator MarR is a copper sensor in Escherichia coli. Nat. Chem. Biol. 2013, 10, 21.

(40) Alekshun, M. N.; Levy, S. B.; Mealy, T. R.; Seaton, B. A.; Head, J. F. The crystal structure of MarR, a regulator of multiple antibiotic resistance, at $2.3 \AA$ A resolution. Nat. Struct. Biol. 2001, 8, 710.

(41) Birukou, I.; Seo, S. M.; Schindler, B. D.; Kaatz, G. W.; Brennan, R. G. Structural mechanism of transcription regulation of the Staphylococcus aureus multidrug efflux operon mepRA by the MarR family repressor MepR. Nucleic Acids Res. 2014, 42, 27742788.

(42) Li, R.; Manna, A. C.; Dai, S.; Cheung, A. L.; Zhang, G. Crystal structure of the SarS protein from Staphylococcus aureus. J. Bacteriol. 2003, 185, 4219-4225.

(43) Chen, P. R.; Bae, T.; Williams, W. A.; Duguid, E. M.; Rice, P. A.; Schneewind, O.; He, C. An oxidation-sensing mechanism is used by the global regulator MgrA in Staphylococcus aureus. Nat. Chem. Biol. 2006, 2, 591-595.

(44) Kahan, F. M.; Kahan, J. S.; Cassidy, P. J.; Kropp, H. The mechanism of action of Fosfomycin (Phosphonomycin). Ann. N.Y. Acad. Sci. 1974, 235, 364-386.

(45) Long, M. J. C.; Aye, Y. Privileged electrophile sensors: A resource for covalent drug development. Cell Chem. Biol. 2017, 24, 787-800.

(46) Gioia, C.; Hauville, A.; Bernardi, L.; Fini, F.; Ricci, A. Organocatalytic asymmetric Diels-Alder reactions of 3-vinylindoles. Angew. Chem., Int. Ed. 2008, 47, 9236-9239. 